\title{
Neuronal Protein Tyrosine Phosphatase 1B Hastens Amyloid $\beta$-Associated Alzheimer's Disease in Mice
}

\author{
Konrad M. Ricke, ${ }^{1,4,5}$ Shelly A. Cruz, ${ }^{1,2}$ Zhaohong Qin, ${ }^{1,2}$ Kaveh Farrokhi, ${ }^{1,2}$ Fariba Sharmin, ${ }^{1,2}$ Li Zhang, ${ }^{1,2}$ \\ Michael A. Zasloff, ${ }^{3} \oplus^{-}$Alexandre F.R. Stewart, ${ }^{4,5,8}$ and ${ }^{\circ H}$ Hiao-Huei Chen ${ }^{1,2,6,7,8}$ \\ ${ }^{1}$ Brain and Mind Research Institute, University of Ottawa, Ottawa, Ontario K1H 8M5, Canada, ${ }^{20 t t a w a ~ H o s p i t a l ~ R e s e a r c h ~ I n s t i t u t e, ~ O t t a w a, ~ O n t a r i o ~ K 1 H ~}$ \\ 8L6, Canada, ${ }^{3}$ MedStar Georgetown Transplant Institute, MedStar Georgetown University Hospital, Washington, DC 20007, ${ }^{4}$ University of Ottawa Heart \\ Institute, Ontario K1Y 4W7, ${ }^{5}$ Biochemistry, Microbiology and Immunology K1H 8M5, ${ }^{6}$ Department of Cellular and Molecular Medicine, ${ }^{7}$ Department of \\ Medicine, and ${ }^{8}$ Centre for Infection, Immunity and Inflammation, University of Ottawa, Ottawa, Ontario K1N 6N5, Canada
}

Alzheimer's disease (AD) is the most common neurodegenerative disorder, resulting in the progressive decline of cognitive function in patients. Familial forms of AD are tied to mutations in the amyloid precursor protein, but the cellular mechanisms that cause AD remain unclear. Inflammation and amyloidosis from amyloid $\beta(\mathrm{A} \beta)$ aggregates are implicated in neuron loss and cognitive decline. Inflammation activates the protein-tyrosine phosphatase $1 \mathrm{~B}$ (PTP1B), and this could suppress many signaling pathways that activate glycogen synthase kinase $3 \beta$ (GSK3 $\beta$ ) implicated in neurodegeneration. However, the significance of PTP1B in AD pathology remains unclear. Here, we show that pharmacological inhibition of PTP1B with trodusquemine or selective ablation of PTP1B in neurons prevents hippocampal neuron loss and spatial memory deficits in a transgenic AD mouse model with A $\beta$ pathology (hAPP-J20 mice of both sexes). Intriguingly, while systemic inhibition of PTP1B reduced inflammation in the hippocampus, neuronal PTP1B ablation did not. These results dissociate inflammation from neuronal loss and cognitive decline and demonstrate that neuronal PTP1B hastens neurodegeneration and cognitive decline in this model of AD. The protective effect of PTP1B inhibition or ablation coincides with the restoration of GSK3 $\beta$ inhibition. Neuronal ablation of PTP1B did not affect cerebral amyloid levels or plaque numbers, but reduced A $\beta$ plaque size in the hippocampus. In summary, our preclinical study suggests that targeting PTP1B may be a new strategy to intervene in the progression of AD.

Key words: Alzheimer's disease; amyloidosis; cognitive decline; inflammation; neurodegeneration; PTP1B

\section{Significance Statement}

Familial forms of Alzheimer's disease (AD) are tied to mutations in the amyloid precursor protein, but the cellular mechanisms that cause $\mathrm{AD}$ remain unclear. Here, we used a mouse model expressing human amyloid precursor protein bearing two familial mutations and asked whether activation of a phosphatase PTP1B participates in the disease process. Systemic inhibition of this phosphatase using a selective inhibitor prevented cognitive decline, neuron loss in the hippocampus, and attenuated inflammation. Importantly, neuron-targeted ablation of PTP1B also prevented cognitive decline and neuron loss but did not reduce inflammation. Therefore, neuronal loss rather than inflammation was critical for AD progression in this mouse model, and that disease progression could be ameliorated by inhibition of PTP1B.

\section{Introduction}

Alzheimer's disease (AD) is the most frequent form of dementia, affecting $\sim 7 \%$ of the North American and European population

Received Aug. 30, 2019; revised Dec. 12, 2019; accepted Dec. 20, 2019.

Author contributions: K.M.R., A.F.R.S., and H.-H.C. designed research; K.M.R., S.A.C., Z.Q., K.F., and F.S. performed research;M.A.Z. contributed unpublished reagents/analytic tools; K.M.R., S.A.C., Z.Q., K.F., F.S., L.Z., A.F.R.S., and H.-H.C. analyzed data; K.M.R., A.F.R.S., and H.-H.C. wrote the paper.

This work was supported by grants from the Alzheimer's Society of Canada (H.-H.C.) and the Weston Brain Institute (H.-H.C. and A.F.R.S.).

M.A.Z. is the $\mathrm{CE} O$ of Enterin (Philadelphia, PA) and is a Professor at Georgetown University. The authors declare no other competing financial interests.

Correspondence should be addressed to Hsiao-Huei Chen at hchen@uottawa.ca or Alexandre F. R. Stewart at astewart@ottawaheart.ca.
$>65$ years of age (Ferri et al., 2005; van der Flier and Scheltens, 2005). Patients with AD display progressive cerebral deterioration, loss of memory, linguistic difficulties, and disorientation (Ballard et al., 2011). The cause of sporadic AD is unresolved, and treatment strategies are directed toward the symptoms, but do not delay the progression of the disease or even prevent its onset (Burns and Iliffe, 2009; David and Gad, 2017).

Mutations in the amyloid precursor protein (APP) are tied to early-onset familial forms of AD (Mullan et al., 1992; Murrell et

https://doi.org/10.1523/JNEUROSCI.2120-19.2019

Copyright $\odot 2020$ the authors 
al., 2000). These mutations change the metabolism of amyloid $\beta$ $(\mathrm{A} \beta)$ peptides and cause the formation of pathogenic aggregates (amyloidosis). In patients with sporadic $\mathrm{AD}$, affected brain areas contain extracellular deposits of oligomerized $\mathrm{A} \beta$ plaques, mainly composed of $\mathrm{A} \beta_{40}$ and $\mathrm{A} \beta_{42}$ species, which are cleaved products of APP (Gandy, 2005). High levels of $A \beta$ result in the formation of nitric oxide, reactive oxygen species, and cytokines that stimulate the inflammatory response in $\mathrm{AD}$ patients, potentially contributing to tissue deterioration (Meraz-Ríos et al., 2013). However, the precise role of cerebral $A \beta$ in neurodegeneration and cognitive decline in $\mathrm{AD}$ patients remains unclear (Bloom, 2014; Spires-Jones and Hyman, 2014), particularly since recent phase III clinical trials (ENGAGE, Clinical trial reg. no. NCT02477800; and EMERGE, Clinical trial reg. no. NCT02484547) targeting extracellular amyloid were terminated early because they failed to show efficacy.

Neuroinflammation and neurodegeneration are common features of familial and sporadic AD. However, it is not clear whether neuroinflammation or neuronal cellular dysfunction per se account for cognitive decline and neurodegeneration. This is particularly relevant since a phase II clinical trial of the nonsteroidal anti-inflammatory drug naproxen failed to prevent the progression of AD (Meyer et al., 2019). Neuroinflammation and stress of the endoplasmic reticulum, both associated with amyloidosis and commonly observed in AD (Selkoe, 1991; Gerakis and Hetz, 2018), result in increased activity of the proteintyrosine phosphatase 1B (PTP1B; Zabolotny et al., 2008; Hakim et al., 2015; Zhu et al., 2015; Song et al., 2016). High PTP1B activity further activates the proinflammatory response of microglia (Song et al., 2016; Tsunekawa et al., 2017), resulting in a vicious cycle.

PTP1B is a key inhibitor of several signaling pathways, including insulin, leptin, mGluR5, and trkB (Pandey et al., 2013, 2014; Ozek et al., 2014; Qin et al., 2015a,b). These metabolism-related signaling pathways are disturbed in AD (Zhang et al., 2012; Bonda et al., 2014; Steculorum et al., 2014). Metabolic impairment is a common $\mathrm{AD}$ characteristic and is likely to contribute to disease progression (Cai et al., 2012). Type 2 diabetes dramatically increases the risk for the development of dementia and AD (Leibson et al., 1997; Luchsinger et al., 2001; Profenno et al., 2010), and positron emission tomography studies have shown that glucose metabolism is substantially reduced in cortical areas of $\mathrm{AD}$ patients, corresponding to cognitive decline and disease progression (Nordberg et al., 2010).

Elevated PTP1B activity also prevents the phosphorylation and constitutive inhibition of glycogen synthase kinase $3 \beta$ (GSK3 $\beta$ ) via its inhibition of the kinase Akt/PKB (Gum et al., 2003). Interestingly, GSK $3 \beta$ is a shared downstream component of the metabolic signaling pathways closely tied to the detrimental changes in brains of AD patients: the activity of GSK3 $\beta$ leads to the formation of $\mathrm{AD}$-associated cerebral deposits (Takashima, 2006; Llorens-Martín et al., 2014), compromises neuronal survival (Alvarez et al., 1999), and interferes with cognitive performance (Hernández et al., 2002).

Since PTP1B activation is associated with amyloidosis and cerebral inflammation and targets many key metabolic and signaling pathways implicated in $\mathrm{AD}$, including GSK3 $\beta$ disinhibition, we asked whether systemic inhibition of PTP1B could ameliorate $\mathrm{AD}$ pathology in a mouse model of familial $\mathrm{AD}$ (hAPP-J20 mice). Furthermore, we tested to what extent neuronspecific activation of $\mathrm{PTP} 1 \mathrm{~B}$ contributes to $\mathrm{AD}$ pathology in these mice.

\section{Materials and Methods}

Animals and trodusquemine treatment. Heterozygous hAPP-J20 mice express the human APP carrying the Swedish and Indiana familial mutations (B6.Cg-Zbtb20Tg(PDGFB-APPSwInd)20Lms/2Mmjax; Mucke et al., 2000). Founder mice were purchased from The Jackson Laboratory, and a colony was bred with PTP1B ${ }^{\text {flx/flx }}$ (Bence et al., 2006) and Camk $2 \alpha$ Cre mice (Casanova et al., 2001) on a C57BL/6 background to generate hAPP-J20 mice with ablation of PTP1B in Camk $2 \alpha$-positive neurons (hAPP-J20 PTP1B KO mice). Genotypes were verified by PCR using genomic DNA isolated from tail or ear biopsy samples.

Clinical grade trodusquemine (provided by Enterin) was administered intraperitoneally 6 times per mouse every $5 \mathrm{~d}$ over a period of 1 month at a dose of $5 \mathrm{mg} / \mathrm{kg}$ body weight starting at 4.5 months of age. The last injection was administered 2 weeks before behavioral experiments. Vehicle-treated controls received sterile saline $(0.9 \% \mathrm{NaCl}$ in water). All animal experiments were approved by the University of Ottawa Animal Care Committee in accordance with guidelines of the Canadian Council on Animal Care and were performed with similar numbers of females and males [trodusquemine cohort: wild-type (WT) vehicle: 7 females, 8 males; WT trodusquemine: 6 females, 4 males; hAPP-J20 vehicle: 5 females, 6 males; hAPP-J20 trodusquemine: 4 females, 6 males; PTP1B KO cohort: WT: 6 females, 7 males; PTP1B KO: 6 females, 6 males; hAPP-J20: 4 females, 5 males; hAPP-J20 PTP1B KO: 4 females, 4 males].

Morris water maze test. The Morris water maze test was conducted with 6-month-old mice in the Faculty of Medicine Behavior Core Laboratory at the University of Ottawa to analyze the ability of mice to learn and remember the location of a submerged platform in a pool containing opaque water. The platform surface was $80 \mathrm{~cm}^{2}$, which corresponds to $0.6 \%$ of the total pool area. Mice underwent habituation to the experimental room, and consecutive experiments were performed between noon and 4:00 P.M. Mice were trained for 5 or $6 \mathrm{~d}$, as indicated (four trials per day with an intertrial interval of $20 \mathrm{~min}$ and a random start location in one of four positions) to find the invisible, submerged platform at a fixed location. Cues around the pool were provided as spatial references. Trials lasted $1 \mathrm{~min}$ or until the mouse found the platform. Mice were guided to the platform if they did not find the platform. Mice stayed on the platform for $15 \mathrm{~s}$ at each trial before being removed to their cages. After the training period, the platform was removed from the pool and the probe trial was executed within $1 \mathrm{~min}$ on the following day. On the probe day, platform area and target quadrant crossings were counted and swimming speed was measured using EthoVision automated video tracking software (Noldus).

Tissue collection for histology and biochemistry. Following behavioral experiments, mice were anesthetized by intraperitoneal injection of ketamine ( $65 \mathrm{mg} / \mathrm{kg}$ body weight), xylazine ( $13 \mathrm{mg} / \mathrm{kg}$ body weight), and acepromazine ( $2 \mathrm{mg} / \mathrm{kg}$ body weight); decapitated; and the brains were quickly removed. One hemisphere was fixed overnight in $4 \%$ paraformaldehyde in PBS ( $137 \mathrm{~mm} \mathrm{NaCl}, 2.7 \mathrm{~mm} \mathrm{KCl}, 10.1 \mathrm{~mm} \mathrm{Na}_{2} \mathrm{HPO}_{4}$ dibasic anhydrous, and $1.8 \mathrm{~mm} \mathrm{KH}_{2} \mathrm{PO}_{4}$ in double-distilled $\mathrm{H} 2 \mathrm{O}\left(\mathrm{ddH}_{2} \mathrm{O}\right)$, pH 7.4 , cryoprotected with increasing concentrations of sucrose $(10 \%$ and $20 \%)$ in $0.1 \mathrm{M}$ phosphate buffer $\left(0.038 \mathrm{M} \mathrm{NaH}_{2} \mathrm{PO}_{4}\right.$ monobasic and 0.162 $\mathrm{M} \mathrm{Na}_{2} \mathrm{HPO}_{4}$ dibasic, $\left.\mathrm{pH} 7.4\right)$ for $5 \mathrm{~d}\left(4^{\circ} \mathrm{C}\right)$, frozen on dry ice, and stored at $-80^{\circ} \mathrm{C}$. Twenty micrometer coronal sections were produced using a microtome (at $-20^{\circ} \mathrm{C}$; model CM1850, Leica) and stored at $-80^{\circ} \mathrm{C}$ until histological analysis. The second hemisphere was flash frozen on dry ice and stored at $-80^{\circ} \mathrm{C}$ until protein extraction for ELISA. For immunoblot analysis, mice were fasted overnight. Following isoflurane anesthesia, mice were decapitated and $300 \mu \mathrm{m}$ hippocampal brain sections were cut in carbonated artificial CSF (ACSF; $124 \mathrm{~mm} \mathrm{NaCl}, 3 \mathrm{~mm} \mathrm{KCl}, 1.3 \mathrm{~mm}$ $\mathrm{MgCl}_{2}, 1.25 \mathrm{~mm} \mathrm{NaH}_{2} \mathrm{PO}_{4}, 26 \mathrm{~mm} \mathrm{NaHCO}_{3}, 2.4 \mathrm{~mm} \mathrm{CaCl}_{2}$, and $10 \mathrm{~mm}$ glucose in $\mathrm{ddH}_{2} \mathrm{O}, \mathrm{pH}$ 7.4) using a vibratome (model VT1000 S, Leica), as described previously (Zaman et al., 2014). Protein was extracted by ultrasonification in RIPA buffer ( $150 \mathrm{~mm} \mathrm{NaCl}, 10 \mathrm{~mm}$ Tris, $\mathrm{pH}$ 7.2, $0.1 \%$ SDS, $1 \%$ Triton X-100, $1 \%$ sodium deoxycholate, and 5 mM EDTA in $\mathrm{ddH}_{2} \mathrm{O}$ ), containing protease and phosphatase inhibitors $[0.5 \mu \mathrm{g} / \mathrm{ml} \mathrm{leu}-$ peptin, $2 \mu \mathrm{g} / \mathrm{ml}$ aprotinin, $0.368 \mathrm{mg} / \mathrm{ml}$ sodium orthovanadate, and 1.74 $\mathrm{mg} / \mathrm{ml}$ phenylmethylsulfonyl fluoride (PMSF)], frozen on dry ice, and stored at $-80^{\circ} \mathrm{C}$. Total protein for all biochemical approaches was quan- 

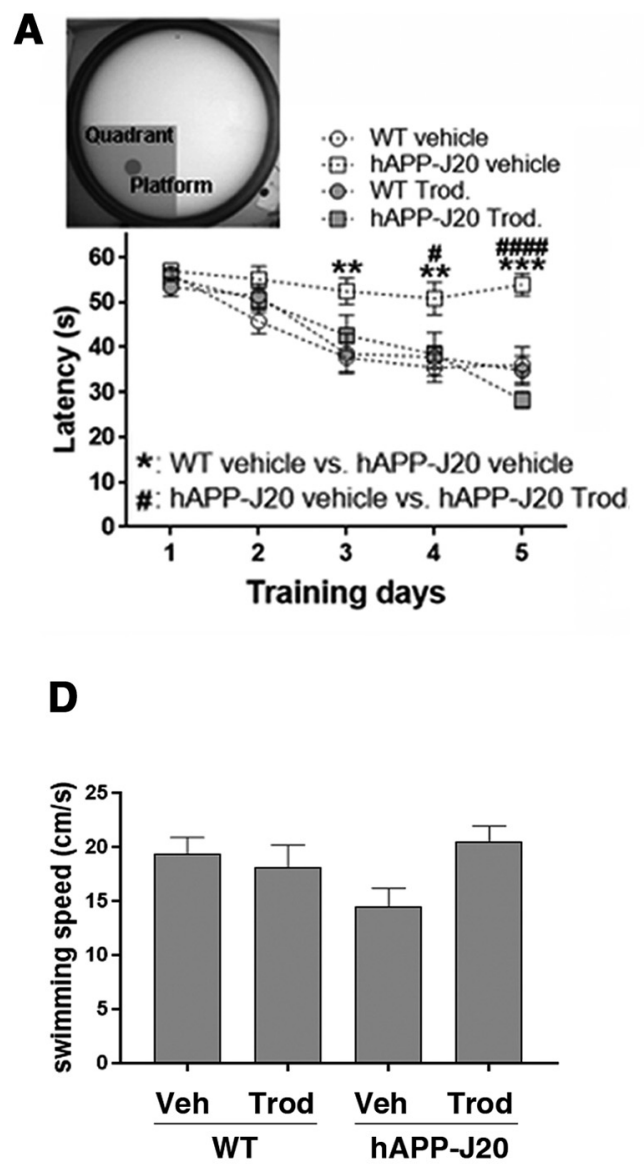

B
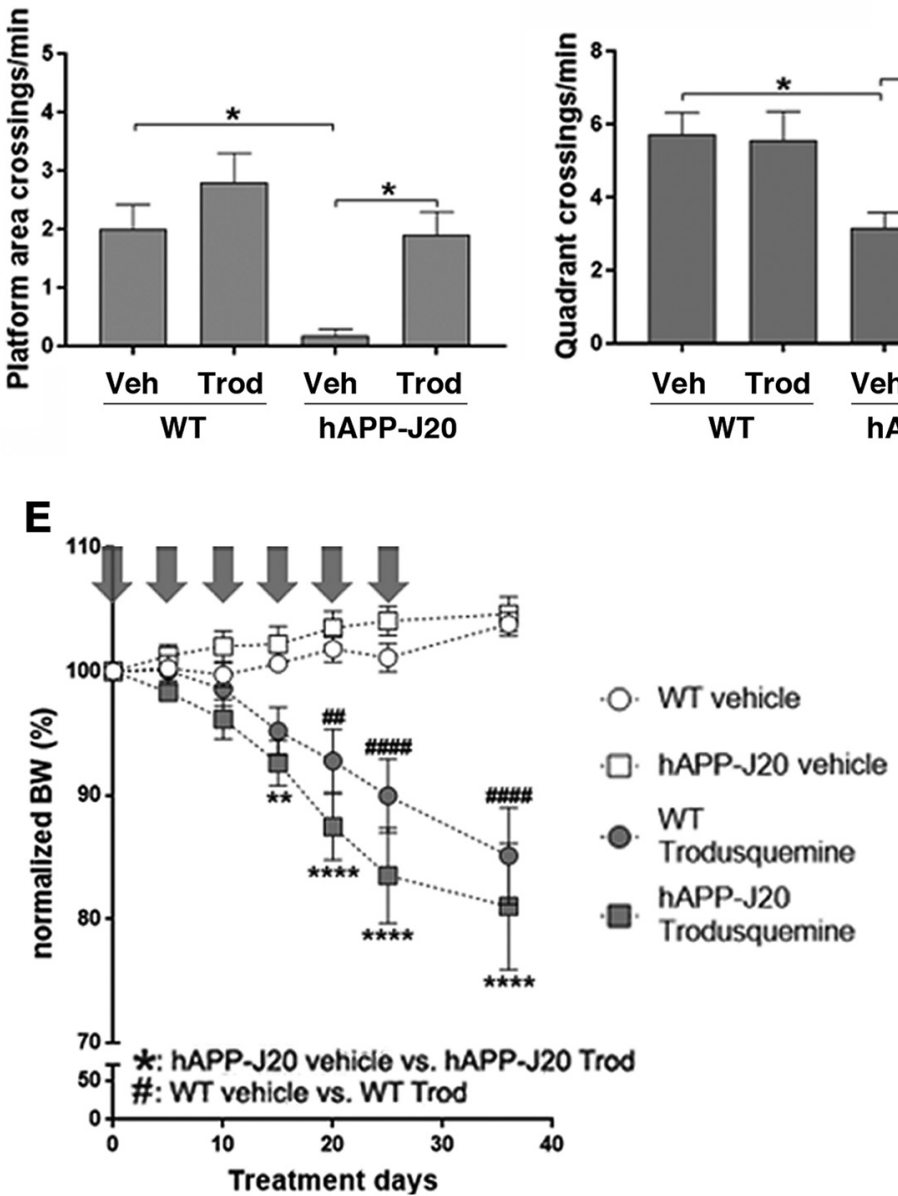

Figure 1. PTP1B inhibition by trodusquemine ameliorates the cognitive impairment of hAPP-J20 mice. $A-C$, Trodusquemine (Trod) treatment over $30 \mathrm{~d}(5 \mathrm{mg} / \mathrm{kg} / 5 \mathrm{~d}$, i.p.) decreased the latency to find the hidden platform for hAPP-J20 mice during the training phase $(\boldsymbol{A})$ and improved memory [crossings at the area where the platform was located $(\boldsymbol{B})$ and target quadrant crossings $(\boldsymbol{C})$ ] on the probe day in Morris water maze experiments. $\boldsymbol{D}$, Swimming speed. $\boldsymbol{E}$, Body weight progression. $n=10-15$ mice/group. $\boldsymbol{A}$, Repeated-measures two-way ANOVA: genotype/treatment, $F_{(3,42)}=6.541, p=0.0010 ;$ time, $F_{(4,168)}=32.52, p<0.0001$; subjects (matching), $F_{(42,168)}=3.668, p<0.0001$; interaction, $F_{(12,168)}=2.993, p=0.0008$. * Post hoc pairwise comparisons between vehicle (Veh) WT and Veh hAPP-J20, days 3, 4, 5: $p=0.0031, p=0.0017, p=0.0002$, respectively; \#post hoc pairwise comparisons between Veh and Trod hAPP-J20, days 4 and 5: $p=$ $0.0368, p<0.0001$, respectively. $B$, Two-way ANOVA: genotype, $F_{(1,42)}=11.11, p=0.0018$; treatment, $F_{(1,42)}=9.532, p=0.0036$; interaction, $F_{(1.42)}=1.267, p=0.2667 .{ }^{*} P_{0 s}$, hoc comparisons between Veh WT and Veh hAPP-J20, $p=0.0101$; and between Veh and Trod hAPP-J20, $p=0.0371$. C, two-way ANOVA: genotype, $F_{(1,42)}=2.864, p=0.0980$; treatment, $F_{(1,42)}=$ $3.775, p=0.0587$; interaction, $\left.F_{(1,42)}=4.595, p=0.0379\right) .{ }^{*}$ Posthoc comparisons between Veh WT and Veh hAPP-J20, $p=0.0365$ and between Veh and Trod hAPP-J20, $p=0.0466 . \mathbf{D}$, Two-way ANOVA: genotype, $F_{(1,42)}=0.5482, p=0.4632$; treatment, $F_{(1,42)}=2.084, p=0.1562$; interaction, $F_{(1,42)}=4.622, p=0.0374$. $\boldsymbol{E}$, Repeated-measures two-way ANOVA: genotype/treatment, $F_{(3,42)}=14.74, p<0.0001$; time, $F_{(6,252)}=17.05, p<0.0001$; subjects (matching), $F_{(42,252)}=8.676, p<0.0001$; interaction, $F_{(18,252)}=14.34, p<0.0001$.

tified using a bicinchoninic acid assay Pierce BCA Protein Assay Kit (Thermo Fisher Scientific).

For in vitro insulin treatment, hippocampal brain coronal sections were recovered in ACSF at $25^{\circ} \mathrm{C}$ for 30 min before vehicle or $100 \mathrm{nM}$ insulin treatment for $10 \mathrm{~min}$, and proteins were extracted for immunoblot analysis.

Histology. Cryostat sections (20 $\mu \mathrm{m}$ thickness) were washed in PBS $(1 \times 5 \mathrm{~min})$, followed by another washing step in PBST $(0.1 \%$ Triton-X in PBS, $3 \times 5 \mathrm{~min}$ ) and blocked in $5 \%$ sheep serum $/ 5 \%$ bovine serum albumin in PBST ( $1 \mathrm{~h}$, room temperature). Sections were incubated with primary antibodies [PTP1B; catalog \#ab245984, Abcam; rabbit: 1:50; GFAP, catalog \#sc6170, Santa Cruz Biotechnology; goat: 1:500; IBA1, catalog \#LKR1186, Wako; rabbit: 1:500 in 5\% sheep serum or bovine serum albumin in PBST, overnight $\left.(\mathrm{o} / \mathrm{n}), 4^{\circ} \mathrm{C}\right]$. After washing in PBST $(3 \times 5 \mathrm{~min})$, sections were incubated with secondary antibodies (Cy5conjugated donkey anti-goat, Cy3-conjugated donkey anti-rabbit, 1:500 in $5 \%$ sheep serum $/ 5 \%$ bovine serum albumin in PBST, $2 \mathrm{~h}$, room tem- perature), followed by another washing step in PBST $(3 \times 5 \mathrm{~min})$ and mounted for fluorescence microscopy. The M.O.M. Kit (mouse on mouse; catalog \#BMK-2202, Vector Laboratories) was used for antibodies from mouse according to the manufacturer protocol: sections were washed in PBS $(3 \times 5 \mathrm{~min})$ and blocked with IgG blocking reagent (1:25 in PBS, $1 \mathrm{~h}$, room temperature). Following another washing step in PBS $(3 \times 5 \mathrm{~min})$, sections were incubated in M.O.M. diluent (M.O.M. protein concentrate, $1: 12.5$ in PBS, $5 \mathrm{~min}$ ). After incubation with primary antibody (human A $\beta$, Dako; clone 6F3D, 1:100; FosB: catalog \#ab11959, Abcam, 1:100; NeuN: catalog \#MAB377, Millipore, 1:500 in M.O.M. diluent, $\left.\mathrm{o} / \mathrm{n}, 4^{\circ} \mathrm{C}\right)$, sections were washed in PBS $(3 \times 5 \mathrm{~min})$ and incubated with biotinylated anti-mouse IgG reagent (1:250 in M.O.M. diluent, $10 \mathrm{~min}$, room temperature), as we described previously (Schock et al., 2008). After another wash with PBS $(3 \times 5 \mathrm{~min})$, sections were incubated with Cy5-conjugated streptavidin (1:500 in PBS, Jackson ImmunoResearch), washed again with PBS $(3 \times 5 \mathrm{~min})$ and mounted for fluorescence microscopy. Nuclei were stained with DAPI (Sigma- 
Aldrich). Heat-induced antigen retrieval for $\mathrm{A} \beta$ and GFAP was performed in $0.1 \mathrm{M}$ sodium citrate buffer ( $0.04 \mathrm{M}$ sodium citrate dihydrate, $0.06 \mathrm{M}$ citric acid), $\mathrm{pH} 6$, at $95^{\circ} \mathrm{C}$ for $20 \mathrm{~min}$ before the blocking step. Dense core plaques were stained with thioflavin S (1\% in $80 \%$ methanol, 15 min; Sigma-Aldrich) after dehydration in $70 \%$ and $80 \%$ ethanol ( 1 min each). $\mathrm{A} \beta$ plaques were identified as thioflavin S-positive patches with a minimal diameter of $8 \mu \mathrm{m}$ and a minimal area of $50 \mu \mathrm{m}^{2}$, similar to the findings of Jährling et al. (2015).

Fluorescence images were obtained using an inverted epifluorescence microscope (Axio Observer.Z1, Zeiss) with a $10 \times(\mathrm{A} \beta$, thioflavin S) or $20 \times$ objective (PTP1B, FosB, GFAP, IBA1, NeuN). Fluorescence microscopy was performed at bregma $-2.18 \mathrm{~mm}$, and two pictures were obtained for each mouse. Quantification was performed with ImageJ software (NIH; https://imagej.net/Fiji/Downloads).

Immunoblots. Fifty micrograms of protein was loaded onto $10 \%$ SDS-polyacrylamide gels and transferred to PVDF membranes at $100 \mathrm{~V}$ for $2.5 \mathrm{~h}$. Blots were blocked with $5 \%$ bovine serum albumin or $5 \%$ nonfat milk in TBST at room temperature for $1 \mathrm{~h}$ and probed with the following primary antibodies (1:1000): phospho-insulin receptor substrate 1 (IRS1; Tyr895; catalog \#3070), IRS1 (catalog \#2382), phospho-GSK3 $\beta$ (Ser9; catalog \#5558), and GSK3 $\beta$, rabbit (catalog \#9315; all from Cell Signaling Technology; PTP1B, rabbit (catalog \#ab245984, Abcam); and $\beta$-actin, mouse (catalog \#A5441, Sigma-Aldrich) at $4^{\circ} \mathrm{C}$ overnight, followed by appropriate horseradish peroxidase (HRP)-conjugated secondary antibodies (1:10,000). HRP signals were detected with ECL (GE Healthcare). Blots were stripped with $0.2 \mathrm{~m}$ glycine, $3.5 \mathrm{~mm}$ SDS, and $1 \%$ Tween 20 in $\mathrm{ddH}_{2} \mathrm{O}$, at $\mathrm{pH} 2.2$, for $20 \mathrm{~min}$ at room temperature between each primary antibody.

ELISA of $A \beta_{40 / 42}$ protein species. Soluble and insoluble protein from mouse brain was extracted in a manner similar to that of Casali and Landreth (2016). Brain hemispheres were mechanically homogenized in ice-cold homogenization buffer [ $2 \mathrm{~mm}$ Tris, pH 7.4, 250 mm sucrose, 0.5 mm EDTA, 0.5 mm EGTA, 1 mm PMSF, and Mini Protease Inhibitor Cocktail (cOmplete, Roche) in RNase-free water]. After adding 0.4\% diethylamine (Sigma-Aldrich) 1:1 to each sample, homogenates were centrifuged $\left(135,000 \times \mathrm{g}, 1 \mathrm{~h}, 4^{\circ} \mathrm{C}\right)$, and supernatants (soluble protein) were flash frozen on dry ice and stored at $-80^{\circ} \mathrm{C}$. Remaining pellets were dissolved by sonification for $1 \mathrm{~min}$ in $200 \mu \mathrm{l}$ of ice-cold formic acid and centrifuged $\left(109,000 \times g, 1 \mathrm{~h}, 4^{\circ} \mathrm{C}\right)$. Supernatants were added 1:20 to formic acid neutralization buffer $(1 \mathrm{M}$ Tris base, $0.5 \mathrm{M}$ $\mathrm{Na}_{2} \mathrm{HPO}_{4}$, and $0.05 \% \mathrm{NaN}_{3}$ in $\mathrm{ddH}_{2} \mathrm{O}$ ) and samples (insoluble protein) were flash frozen on dry ice and stored at $-80^{\circ} \mathrm{C}$ until further analysis.

The soluble fraction contained $2.5 \mathrm{mg} / \mathrm{ml}$ and the insoluble fraction contained $0.06 \mathrm{mg} / \mathrm{ml}$ protein on average. ELISA experiments were conducted using ELISA kits for human $\mathrm{A} \beta_{40}$ and $\mathrm{A} \beta_{42}$-protein (KHB3481 and KHB3441, Thermo Fisher Scientific) according to manufacturer instructions with 10 -fold dilutions of extracted protein. $A \beta$ protein levels and detection thresholds given by the manufacturer were normalized to total protein.

Statistics. Statistical analysis was performed with GraphPad Prism 7. Quantified data in figures are presented as the mean \pm SEM, and relative data are shown as the percentage of control experiments (WT or vehicletreated WT). Percentages and ratios were normalized by arcsine transformation. Unpaired Student's $t$ tests were used for two-group

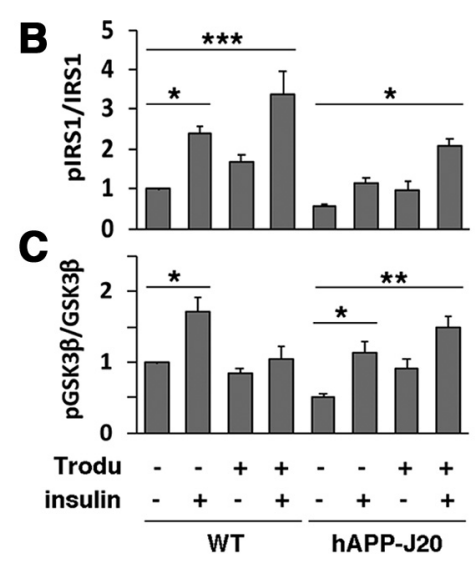

E

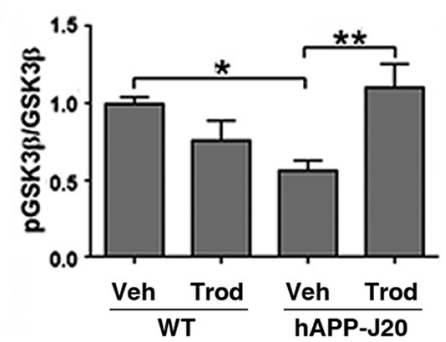

Figure 2. PTP1B inhibition by trodusquemine (Trod) restores insulin response and phosphorylated/inactive GSK3 $\beta$ in hAPP-J20 on 列

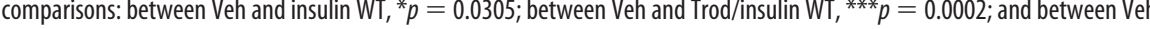

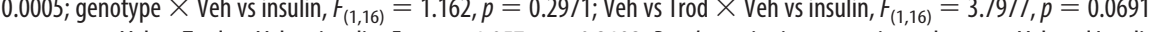
$X$ Veh vs Trod $\times$ Veh vs insulin, $F_{(1,16)}=1.057, p=0.3192$. Post hoc pairwise comparisons: between Veh and Insulin acutely isolated brain sections, mas rescued when hAPP-J20 mice were chronically treated with trodusquemine. Blots are quantified in $\boldsymbol{E}(n=5-7$ mice, two-way ANOVA: genotype, $F_{(1,19)}=0.1750, p=0.6804$; treatment, $F_{(1,19)}=2077, p=0.1658$; interaction, $F_{(1,19)}=13.69, p=0.0015 ;$ posthoc pairwise comparisons between Veh WT and Veh hAPP-J20, ${ }^{*} p=0.0480$; and between Veh and Trod hAPP-J20, ${ }^{* *} p=0.0092$ ).

comparisons. Four-group comparisons were analyzed by two-way ANOVA (repeated-measures ANOVA with adjusted $p$ values for training effects in Morris water maze experiments and for body weight) followed by Bonferroni post hoc comparisons when at least one of the main factors or the interaction was significant. For three-way ANOVA of immunoblots comparing genotypes, trodusquemine, and insulin treatments, Tukey's multiple-comparison test was used. A significance level of 0.05 was accepted for all statistical tests. Asterisks mark $p$ values $\leq 0.05\left(^{*}\right)$, $\leq 0.01\left(^{* *}\right), \leq 0.001\left(^{* * *}\right)$, or $\leq 0.0001\left(^{* * * *}\right)$. The results of all statistical analyses are presented in each figure legend and in the text, when appropriate.

\section{Results}

\section{Systemic inhibition of PTP1B improves the behavioral AD phenotype of hAPP-J20 mice}

$\mathrm{AD}$ is commonly associated with loss of memory (Ballard et al., 2011) and hAPP-J20 mice display similar impairment of cognitive function (Palop et al., 2003; Royea et al., 2017). Trodusquemine is a noncompetitive and highly selective PTP1B inhibitor (Lantz et al., 2010; Pandey et al., 2013, 2014; Krishnan et al., 2014; Qin et al., 2015b; Banh et al., 2016), which has been used for the intervention of diabetes and obesity in clinical trials (Nguyen et 
A

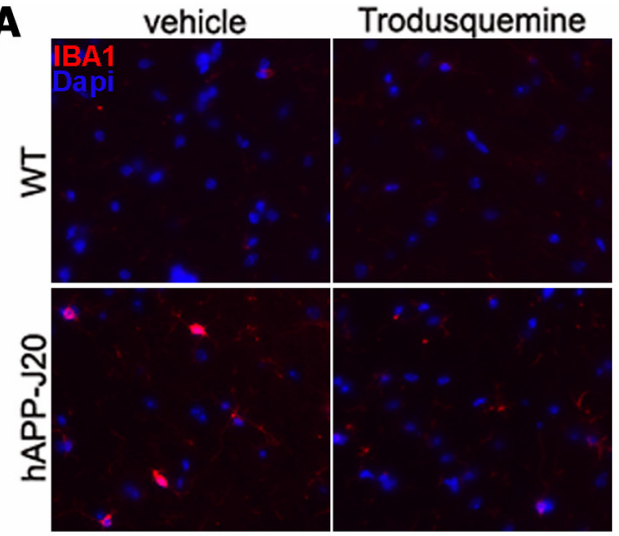

B
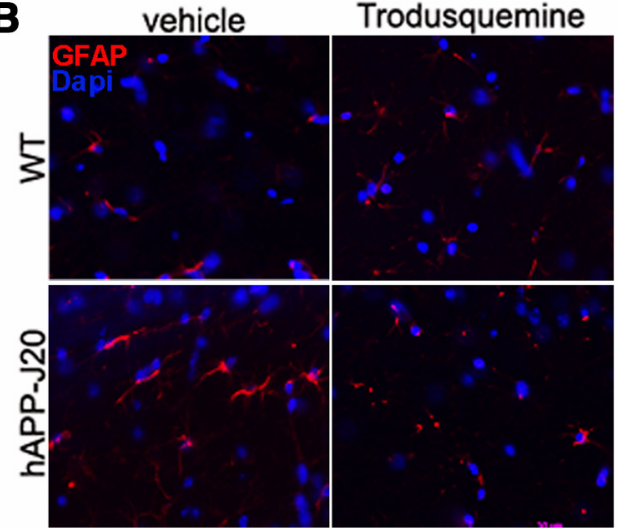

C

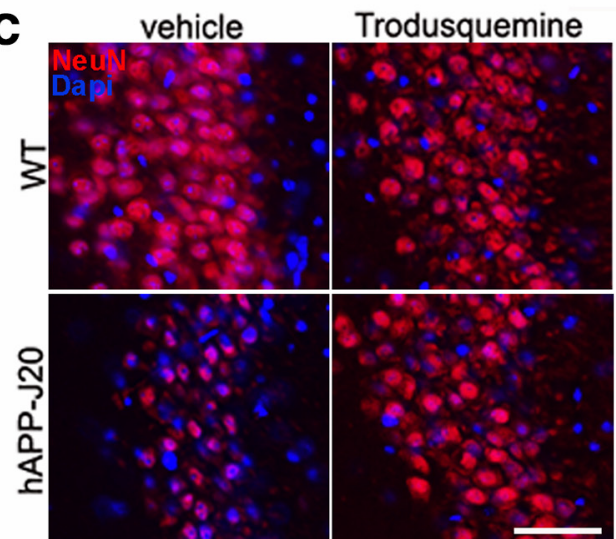

D

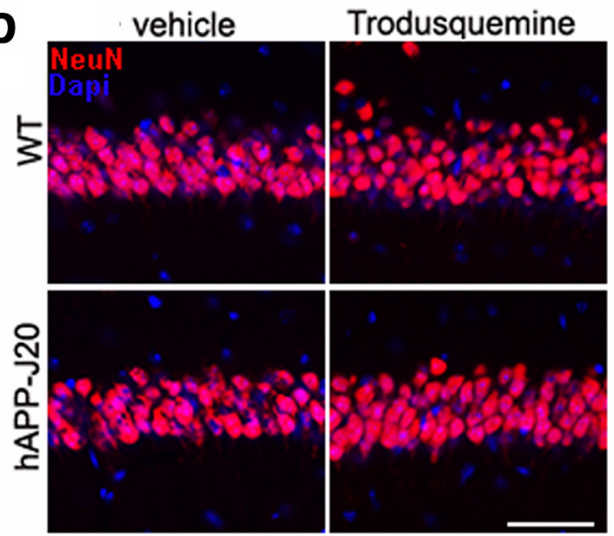

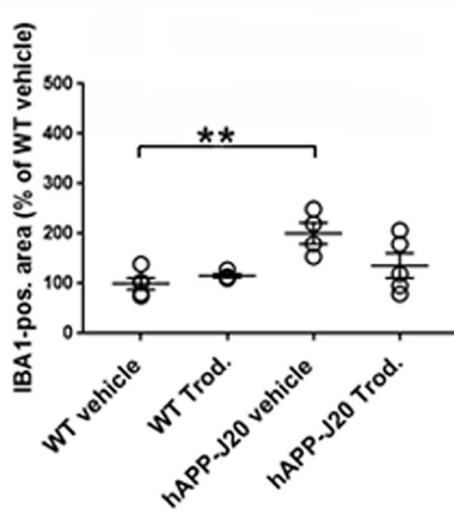
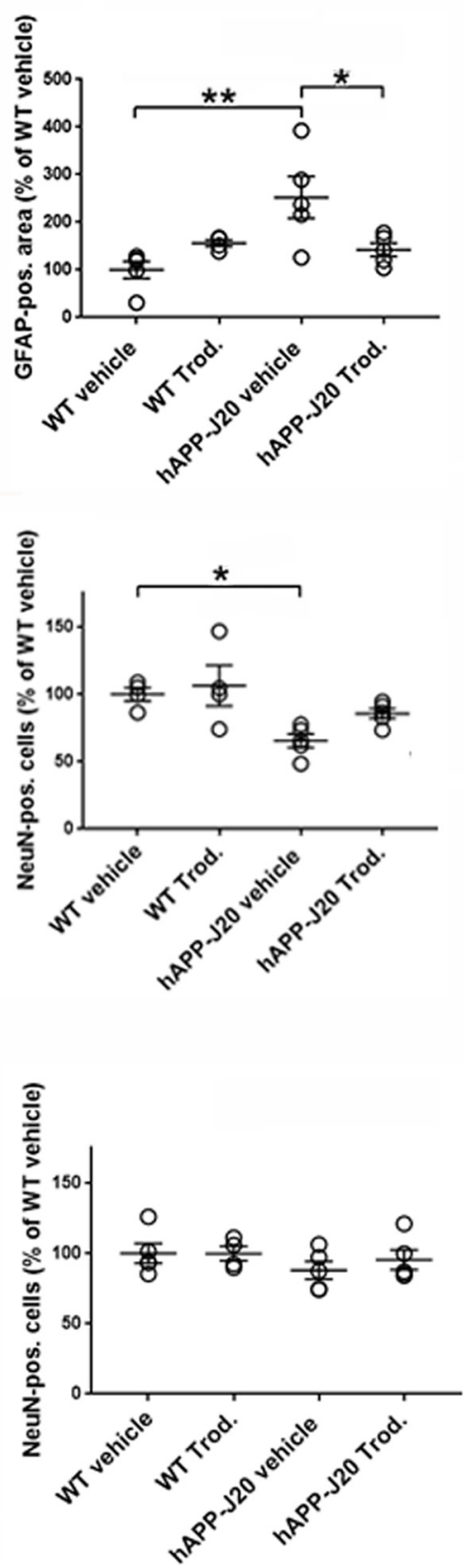

Figure 3. PTP1B inhibition by trodusquemine (Trod) reduces inflammation and neuron loss in the hippocampus CA3 region of hAPP-J20 mice. $\boldsymbol{A}, \boldsymbol{B}$, Inflammation was assessed by IBA1 $(\boldsymbol{A})$ and GFAP $(\boldsymbol{B})$ immunostaining in the hippocampal CA3 region. $\boldsymbol{C}, \boldsymbol{D}$ Neurons identified by NeuN immunostaining were counted in CA3 $(\boldsymbol{C})$ and CA1 (D). Nuclei are counterstained with DAPI. Scale bars, $50 \mu \mathrm{m} . n=4-5$ mice/group. Two-way ANOVA for IBA1: genotype, $F_{(1,14)}=11.31, p=0.0046$; treatment, $F_{(1,14)}=1.842$ al., 2013). We have previously reported that a single dose of trodusquemine could ameliorate anxiety-related behaviors in a transgenic mouse model by inhibiting PTP1B (Qin et al., 2015b). Here, we tested whether repeated administration of trodusquemine $(5 \mathrm{mg} / \mathrm{kg}$, i.p., every $5 \mathrm{~d}$ for 6 doses) could improve spatial memory in hAPP-J20 mice in the Morris water maze test (Fig. $1 A-C$ ). By repeated-measures two-way ANOVA, we observed significant main effects of genotype/treatment $\left[F_{(3,42)}=6.541, p=0.0010\right.$; time, $F_{(4,168)}=$ $32.52, p<0.0001$; subjects (matching), $\left.F_{(42,168)}=3.668, p<0.0001\right]$ as well as the interaction between genotype/treatment and time $\left(F_{(12,168)}=2.993, p=0.0008\right)$. During the training phase, vehicle-treated hAPP-J20 mice took longer to find the hidden platform compared with vehicletreated WT mice (Fig. 1A, ${ }^{\star}$ for post hoc analyses). There was no significant difference between trodusquemine and vehicle-treated WT mice. Importantly, trodusquemine treatment improved spatial learning and memory of hAPP-J20 mice, with a shorter latency compared with vehicle-treated hAPP-J20 mice (Fig. 1A, \# for post hoc analyses). Similarly, on the probe day, hAPP-J20 mice had difficulty remembering the precise location (Fig. $1 B$; two-way ANOVA: genotype, $F_{(1,42)}=11.11, p=$ 0.0018 ; treatment, $F_{(1,42)}=9.532, p=$ 0.0036; interaction, $F_{(1,42)}=1.267, p=$ 0.2667 ) or even the quadrant (Fig. $1 C$; two-way ANOVA: genotype, $F_{(1,42)}=$ 2.864, $p=0.0980$; treatment, $F_{(1,42)}=$ $3.775, p=0.0587$; interaction, $F_{(1,42)}=$ $4.595, p=0.0379)$ where the hidden platform had been during training. Trodusquemine treatment rescued these spatial memory deficits in hAPP-J20 mice. No difference in swimming speeds was observed (Fig. 1D).

Consistent with previous studies (Zasloff et al., 2001; Pandey et al., 2013, 2014), chronic trodusquemine-induced weight loss to the same extent in WT and

\footnotetext{
$p=0.1962 ;$ interaction, $F_{(1,14)}=5.010, p=0.0420$. Posthoc pairwise comparison between vehicle (Veh) WT and Veh hAPP-J20, ${ }^{* *} p=0.0085$. Two-way ANOVA for GFAP: genotype, $F_{(1,15)}=6.853, p=0.0194$; treatment, $F_{(1,15)}=1.057$, $p=0.3202$; interaction $F_{(1,15)}=9.893, p=0.0067$. Post hoc pairwise comparisons between Veh WT and Veh hAPP-J20, ${ }^{* *} p=0.0046$; and between Veh and Trod hAPP-J20, ${ }^{*} p=$ 0.0494. Two-way ANOVA for NeuN in CA3: genotype, $F_{(1,14)}=$ $12.48, p=0.0033$; treatment, $F_{(1,14)}=2.904, p=0.1104$; interaction, $F_{(1,14)}=0.8006, p=0.3860$. Post hoc pairwise comparison between Veh WT and Veh hAPP-J20, ${ }^{*} p=$ 0.0442. Two-way ANOVA for NeuN in CA1: genotype, $F_{(1,15)}=$ $1.555, p=0.2315$; treatment, $F_{(1,15)}=0.302, p=0.5907$; interaction, $F_{(1,15)}=0.3264, p=0.5762$.
} 
A

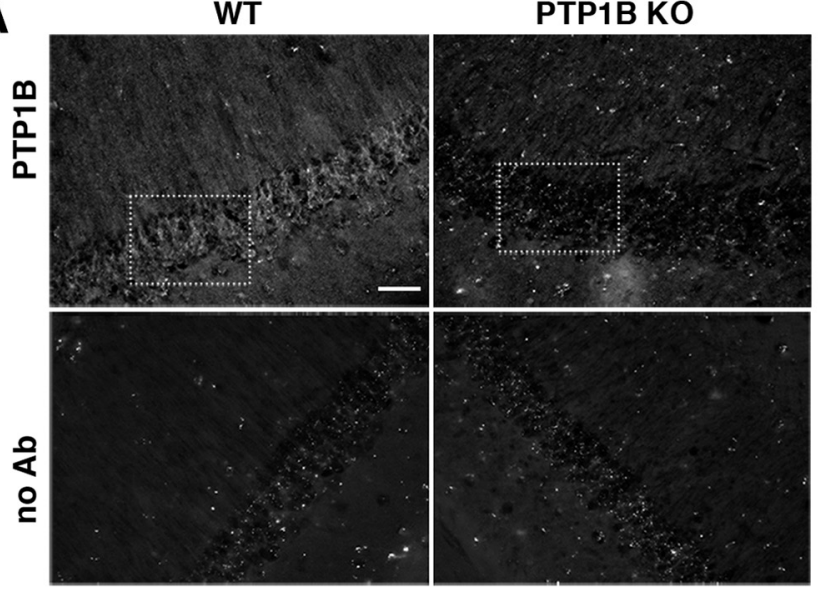

B

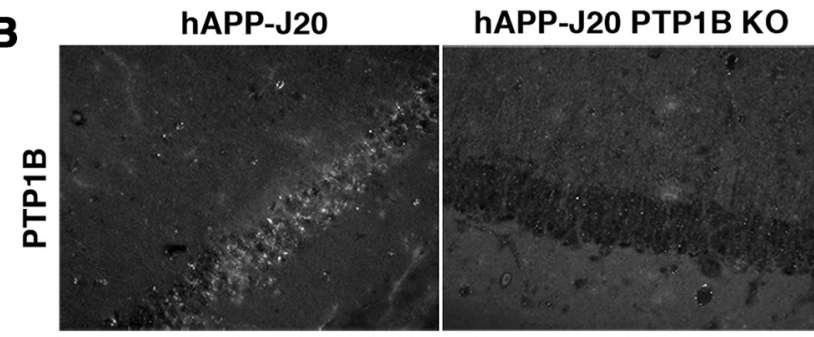

C
음
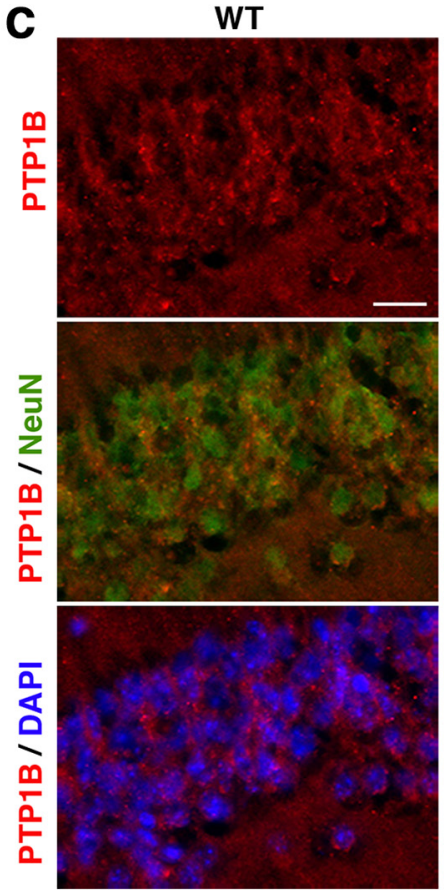

D

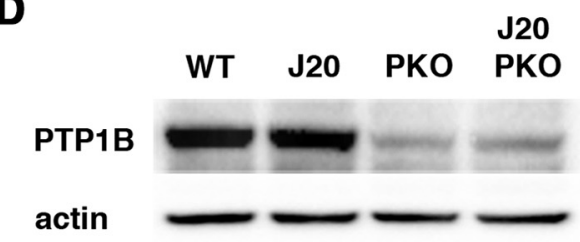

$\mathbf{E}$

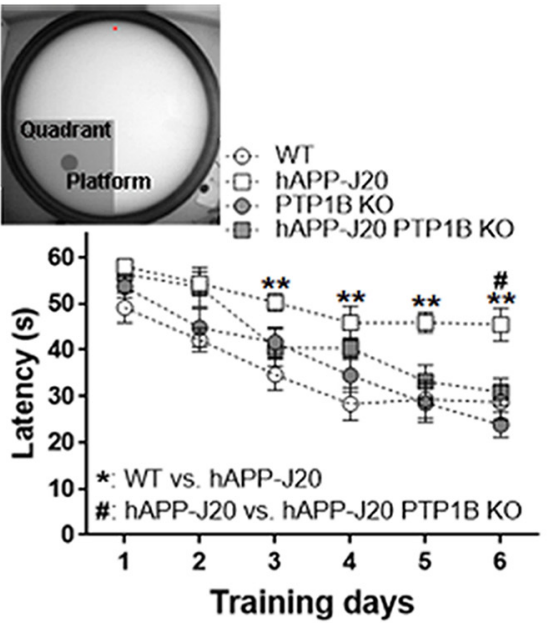

$\mathbf{F}$

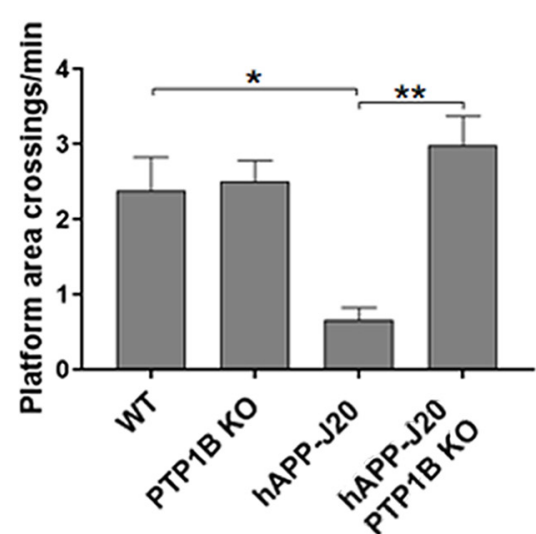

G

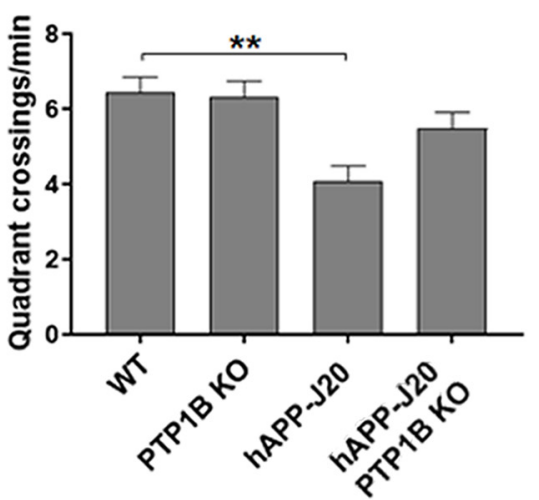

Figure 4. Neuronal PTP1B ablation prevents cognitive deficits in hAPP-J20 mice. $A, B$, Immunofluorescence staining of cryostat brain sections reveal loss of PTP1B in hippocampal neurons of PTP1B KO $(\boldsymbol{A})$ and hAPP-J20 PTP1B KO $(\boldsymbol{B})$ mice. Dashed areas are enlarged in $\boldsymbol{C}$, showing that cytoplasmic PTP1B staining in neurons is lost with PTP1B ablation. NeuN labels neurons and DAPI labels nuclei. Scale bars: $\boldsymbol{A}, 50 \mu \mathrm{m} ; \boldsymbol{C}, 20 \mu \mathrm{m}$. D, Immunoblot of acute brain slices shows marked reduction of PTP1B in PTP1B K0 and hAPP-J20 PTP1B K0 mice. E, Spatial learning and memory were impaired in 6-month-old hAPP-J20 mice over the $6 \mathrm{~d}$ training phase of the Morris water maze test, as measured by the latency to locate the hidden platform using spatial reference cues. $\boldsymbol{F}, \mathbf{G}, 0$ n the probe day, hAPP-J20 mice seldom crossed the platform area ( $\boldsymbol{F}$, where the platform had been located during training) or the target quadrant ( $\boldsymbol{G}$ ). These deficits were rescued in hAPP-J20 mice with neuronal ablation of PTP1B $\left(n=8-13\right.$ mice/group; repeated-measures two-way ANOVA for $\boldsymbol{E}$, genotype, $F_{(3,38)}=8.033, p=0.0003$; time, $F_{(5,190)}=37.45, p<0.0001$; subjects (matching), $F_{(38,190)}=3.925, p<0.0001$; interaction, $F_{(15,190)}=1.385, p=0.1579$. Post hoc pairwise comparisons between WT and hAPP-J20: *days 3, 4, 5, 6: $p=0.0070, p=0.0016, p=0.0033, p=0.0031$, respectively; and between hAPP-J20 and hAPP-J20/PTP1BK0, \#p=0.0230. Tw0-way ANOVA for $F$ : genotype, $F_{(1,38)}=2.731, p=0.1067$; PTP1B deletion, $F_{(1,38)}=11.04, p=0.0020$; interaction, $F_{(1,38)}=9.056, p=0.0046$. Post hoc pairwise comparisons between Veh WT and Veh hAPP-J20, ${ }^{*} p=0.01$; and between Veh and Trod hAPP-J20, ${ }^{* *} p=0.0013$. Two-way ANOVA for $G$, genotype, $F_{(1,38)}=14.13, p=0.0006 ;$ PTP1B deletion, $F_{(1,38)}=2.215, p=0.1449$; interaction, $\left.F_{(1,38)}=3.208, p=0.0813\right)$. Post hoc pairwise comparison between Veh WT and Veh hAPP-J20, ${ }^{*} p=0.017$. 


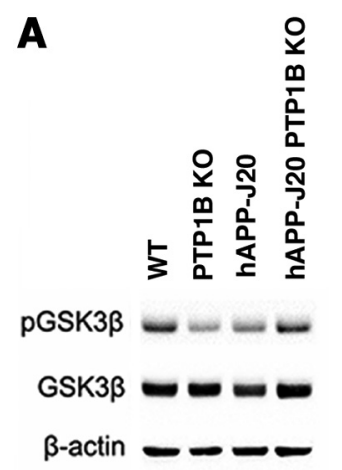

B

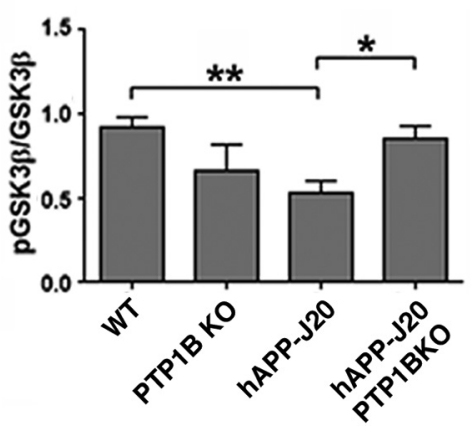

Figure 5. Neuronal PTP1B ablation restores the phosphorylated/inactive form of GSK3 $\beta$ in hAPP-J20 mice. $A, B$, Brain sections were subjected to immunoblot analysis $(A)$ to compare the Ser9-phosphorylated (inactive) form of cerebral GSK3 $\beta$ to total GSK3 $\beta$, quantified in $\boldsymbol{B} . n=$ $3-8$ mice/genotype. Two-way ANOVA: genotype, $F_{(1,20)}=1.371, p=0.2555$; PTP1B deletion, $F_{(1,20)}=0.1390, p=0.7132$; interaction, $\left.F_{(1,20)}=11.63, p=0.0028\right)$. Post hoc pairwise comparisons between WT and hAPP-J20, ${ }^{* *} p=0.0095$; and between hAPP-J20 and hAPP-J20 PTP1BKO, ${ }^{*} p=0.0363$.

hAPP-20 mice (Fig. 1E). By repeated-measures two-way ANOVA, we found significant main effects of genotype/treatment $\left(F_{(3,42)}=14.74, p<0.0001\right)$, time $\left(F_{(6,252)}=17.05, p<\right.$ 0.0001 ), subjects (matching; $F_{(42,252)}=8.676, p<0.0001$ ), as well as their interaction $\left(F_{(18,252)}=14.34, p<0.0001\right)$. Of note, even though behavior tests were performed 2 weeks after the last dose of trodusquemine, spatial learning and memory deficits were clearly rescued in hAPP-J20 mice.

\section{Inhibition of PTP1B restores insulin response and GSK3 $\beta$ inhibition in hAPP-J20 mice}

We next tested whether PTP1B inhibition by chronic trodusquemine would affect the tyrosine phosphorylation of IRS1 (Goldstein et al., 2000; Pandey et al., 2014) and the downstream phosphorylation state of GSK3 $\beta$. Brain sections from mice treated with six doses of trodusquemine or vehicle (Fig. 1D) were kept in ACSF for $30 \mathrm{~min}$ before vehicle or $100 \mathrm{~nm}$ insulin treatment for $10 \mathrm{~min}$, and proteins were analyzed by immunoblot. Inhibition of PTP1B by chronic trodusquemine treatment increased pIRS1 levels and improved the insulin response in hAPPJ20 mice (Fig. $2 A, B$ ). Similar effects were also observed for pGSK3 $\beta$ (Fig. $2 A, C$ ).

Further immunoblot analysis of acutely isolated brain slices revealed a reduced ratio of baseline phosphorylated GSK3 $\beta$ (pGSK $3 \beta$ ) to unphosphorylated GSK3 $\beta$ in hAPP-J20 mice (Fig. $2 D, E)$ relative to wild-type mice. Chronic trodusquemine treatment restored the pGSK $3 \beta$-to-GSK $3 \beta$ ratio in hAPP- 20 mice, when compared with vehicle-treated hAPP-J20 mice. Interestingly, trodusquemine did not affect the pGSK $3 \beta$-to-GSK $3 \beta$ ratio in WT mice, suggesting that GSK $3 \beta$ is largely inhibited in WT mice.

Inhibition of PTP1B reduces inflammation in hAPP-J20 mice hAPP-J20 mice are reported to exhibit elevated degrees of inflammation, which may contribute to cerebral deterioration and cognitive dysfunction (Wright et al., 2013; Royea et al., 2017). Increased activation of innate immune cells (microglia) as shown by IBA immunostaining was detected in the hippocampus CA3 region of hAPP-J20 mice (Fig. $3 A$ ). In addition, increased gliosis was observed by immunostaining for the astrocyte marker GFAP (Fig. 3B). Vehicle-treated hAPP-J20 mice had a greater IBA1- positive area compared with vehicle-treated WT mice. Trodusquemine treatment prevented an increase in the IBA1-positive area in hAPP-J20 mice, implying that trodusquemine attenuates microgliosis in hAPP-J20 mice. Similarly, GFAP-positive area was greater in vehicle-treated hAPP-J20 mice compared with vehicle-treated WT mice and was markedly reduced by trodusquemine treatment (Fig. $3 B$ ). Thus, systemic inhibition of PTP1B decreases inflammation in the hippocampus of hAPP-J20 mice.

\section{Inhibition of PTP1B prevents neurodegeneration in hAPP-J20 mice}

hAPP-J20 mice display aging-associated neurodegeneration in the hippocampus (Wright et al., 2013). To determine whether PTP1B inhibition affects neuron loss to account for its effect on preserving cognitive function in hAPP-J20 mice, we compared neuronal numbers by quantifying NeuN-positive cells in the pyramidal cell layer of hippocampal regions. Vehicle-treated hAPPJ20 contained significantly fewer neurons in the CA3 region (Fig. $3 C$ ), but not in the CA1 region (Fig. $3 D$ ), compared with WT mice. This neuron loss was prevented when hAPP-J20 mice were treated with trodusquemine.

No difference in FosB immunostaining, an index of neuronal activity, was observed in the hippocampus of hAPP-J20 and WT mice (data not shown). Thus, neuron loss and behavioral deficits are not associated with changes in neuronal activity measured by FosB expression. These results imply that systemic inhibition of PTP1B averts hippocampal neuron loss in hAPP-J20 mice.

\section{Neuronal ablation of PTP1B preserves spatial memory in hAPP-J20 mice}

Since systemic administration of a selective PTP1B inhibitor ameliorated spatial memory deficits in hAPP-J20 mice, we next asked to what extent neuronal PTP1B activation accounts for these functional deficits. PTP1B was selectively ablated in glutamatergic neurons of CaMKII $\alpha$ Cre mice (PTP1B KO), and these mice were bred onto the hAPP-J20 background. PTP1B ablation was confirmed by immunohistochemistry (Fig. 4A-C) and immunoblot analysis of brain sections through the hippocampus (Fig. 4D).

In the Morris water maze test, using the same spatial reference cues, hAPP-J20 mice took longer to find the hidden platform than WT mice. Neuronal ablation of PTP1B in hAPP-J20 mice reduced the time needed to find the hidden platform to that seen in WT mice. No difference was seen between PTP1B KO and WT mice (Fig. 4E). On the probe day, hAPP-J20 mice displayed fewer crossings of the precise platform area compared with WT mice and this deficit was rescued by neuronal PTP1B ablation (Fig. $4 F$ ), indicating that neuronal ablation of PTP1B prevents the cognitive decline in this AD mouse model. Similarly, fewer target quadrant crossings (Fig. 4G) were also observed in hAPP-J20 mice compared with WT mice. Importantly, this reduction of target quadrant crossings was not observed with neuronal ablation of PTP1B. Of note, unlike the previously described NestinCre/PTP1Bflox mice, in which PTP1B is ablated in all neuroprogenitors and reduced adiposity and increased energy expenditure are displayed (Bence et al., 2006), neuronal ablation of PTP1B in glutamatergic projection neurons did not affect body weight at 4 months when compared with WT mice $(25.1 \pm 1.5 \mathrm{vs}$ $27.8 \pm 1.6 \mathrm{~g}, p=0.30, n=7$ and 15 mice, respectively). 
Neuronal ablation of PTP1B restores GSK3 $\beta$ phosphorylation in hAPP-J20 mice

Since systemic inhibition of PTP1B restored the phosphorylation of cerebral GSK3 $\beta$ in hAPP-J20 mice (Fig. 2), we asked whether neuronal ablation of PTP1B would have a similar effect (Fig. 5). Remarkably, neuronal ablation of PTP1B in hAPP-J20 mice was sufficient to restore the $\mathrm{pGSK} 3 \beta / \mathrm{GSK} 3 \beta$ ratio compared with hAPP-J20 mice. Thus, neuronal PTP1B activation largely accounts for reduced phosphorylation of GSK3 $\beta$ in hAPP-J20 mice.

\section{Neuronal PTP1B KO does not attenuate} inflammation in hAPP-J20 mice

Since systemic PTP1B inhibition was found to reduce inflammation in hAPPJ20 mice, we asked whether neuronspecific ablation of PTP1B would have a similar effect (Fig. 6). Remarkably, inflammation was not affected by neuronal ablation of PTP1B: a similar elevation in IBA1-reactive areas (Fig. 6A) and GFAPpositive areas (Fig. 6B) was observed in the hippocampus $\mathrm{CA} 3$ region of both hAPP-J20 and hAPP-J20 PTP1B KO mice compared with WT mice. The IBA1positive and GFAP-positive areas were not different between PTP1B KO and WT mice. Thus, the ablation of PTP1B in glutamatergic neurons does not prevent neuroinflammation in hAPP-J20 mice.

\section{Neuronal ablation of PTP1B ameliorates neuron loss of hAPP-J20 mice}

Because systemic inhibition of PTP1B prevented neuron loss in hAPP-J20 mice, we asked to what extent neuron loss is due to neuronal PTP1B activation (Fig. 6). Again, hAPP-J20 mice contained fewer neurons in the $\mathrm{CA} 3$ region compared with WT mice. This neuron loss was prevented by neuronal ablation of PTP1B. Together, these results indicate that in the absence of neuronal PTP1B, inflammation is not sufficient to cause hippocampal neurodegeneration in hAPP-J20 mice.

\section{Neuronal PTP1B increases $A \boldsymbol{\beta}$ plaque} size without altering $A \beta$ protein levels To determine whether neuronal PTP1B also affects the levels of $A \beta$ proteins in hAPP-J20 mice, we analyzed $\mathrm{A} \beta$ protein burdens in hAPP-J20 and hAPP-J20 PTP1B KO mice using ELISA (Fig. 7). Since we did not detect significant amyloidosis before 12 months of age (Fig. $7 A, B$ ), only 12month-old mice were used to examine the effect of neuronal PTP1B ablation on $\mathrm{A} \beta$ burden. $\mathrm{A} \beta_{42}$ is more prone to form $\mathrm{A} \beta$ oligomers and aggregates compared with $\mathrm{A} \beta_{40}$ (Kayed et al., 2003). Interestingly, we did not detect significant differences in $\mathrm{A} \beta_{40}$ and $\mathrm{A} \beta_{42}$ protein levels between hAPP-J20 and hAPP-J20
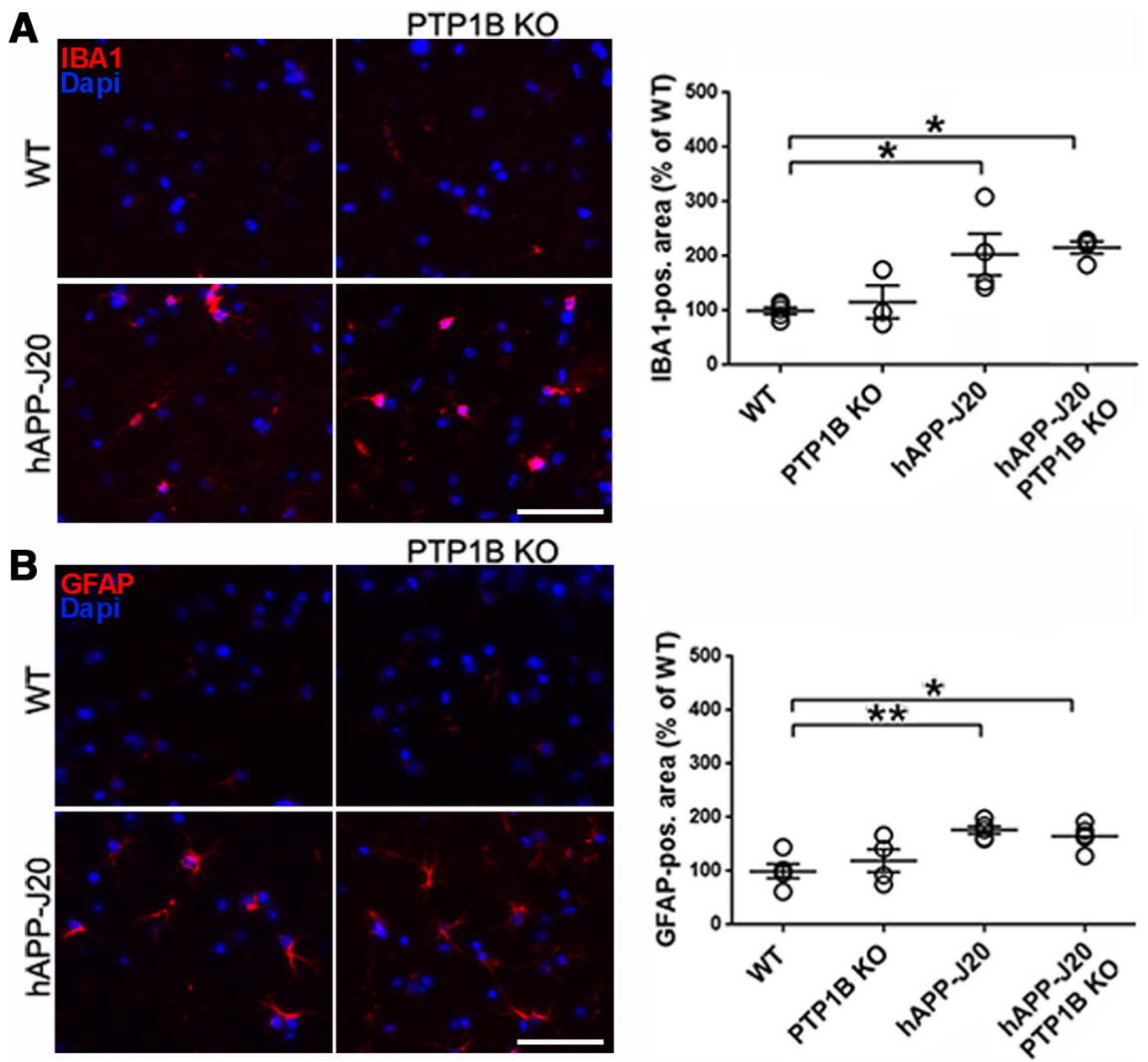

PTP1B KO
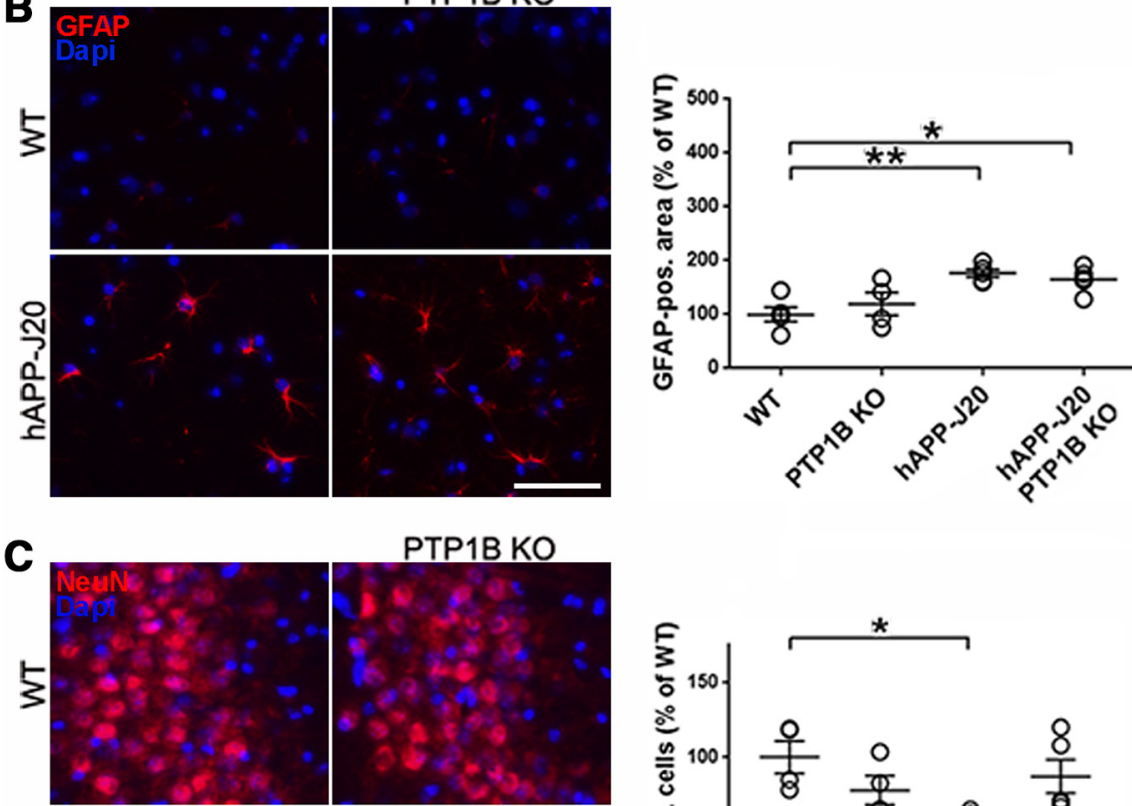

Figure 6. Neuronal PTP1B ablation does not affect inflammation but prevents neuron loss in the hippocampus of hAPP-J20 mice. $\boldsymbol{A}, \boldsymbol{B}$, Inflammation was assessed by IBA1 $(\boldsymbol{A})$ and GFAP $(\boldsymbol{B})$ immunostaining in the CA3 hippocampal region. $\boldsymbol{C}$, Neurons identified by NeuN immunostaining were counted. Nuclei are counterstained with DAPI. Scale bars, $50 \mu \mathrm{m} . n=3-5$ mice/group. Two-way ANOVA for IBA1: genotype, $F_{(1,12)}=18.17, p=0.0011$; PTP1B deletion, $F_{(1,12)}=0.2628, p=0.6175$; interaction, $F_{(1,12)}=0.03385, p=0.8571$. Post hoc pairwise comparisons between WT and hAPP-J20, ${ }^{*} p=0.0335$; and between WT and hAPP-J20 PTP1B K0, ${ }^{*} p=0.0212$. Two-way ANOVA for GFAP: genotype, $F_{(1,15)}=21.76, p=0.0003 ;$ PTP1B deletion, $F_{(1,15)}=$ $0.0953, p=0.7618$; interaction, $F_{(1,15)}=1.371, p=0.2599$. Post hoc pairwise comparisons between WT and hAPP-J20, ${ }^{* *} p=$ 0.0042 ; and between WT and hAPP-J20 PTP1B KO, ${ }^{*} p=0.015$. Two-way ANOVA for NeuN: genotype, $F_{(1,14)}=3.023, p=0.1040$; PTP1B deletion, $F_{(1,14)}=0.0927, p=0.7653$; interaction, $\left.F_{(1,14)}=7.569, p=0.0156\right)$. Post hoc pairwise comparison between WT and hAPP-J20, ${ }^{*} p=0.0405$.
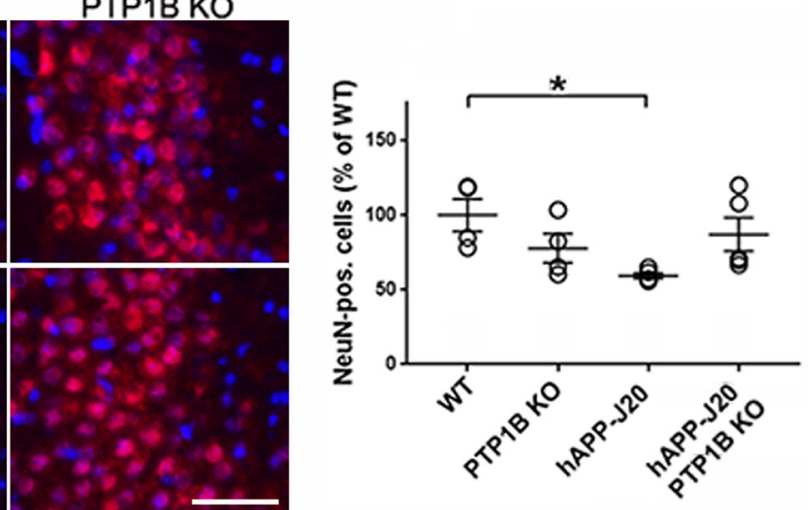

PTP1B KO mice in the soluble or the insoluble protein fractions, indicating that neuronal $\mathrm{PTP} 1 \mathrm{~B}$ does not affect $\mathrm{A} \beta$ protein levels in hAPP-J20 mice (Fig. 7C).

We next quantified the accumulation of cerebral plaques in 12-month-old hAPP-J20 PTP1B KO mice to determine whether neuronal PTP1B alters plaque load. While neuronal PTP1B ablation had no effect on the number of thioflavin S-positive plaques of hAPP-J20 mice (Fig. 7D), total thioflavin S-positive plaque areas were dramatically reduced in the hippocampus of hAPP- 
A

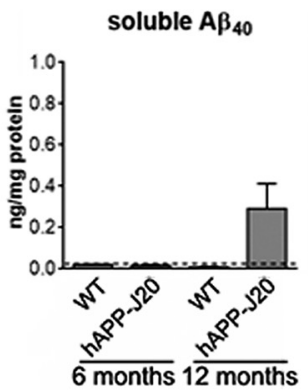

soluble $A \beta_{42}$

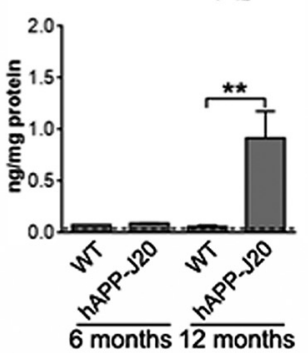

insoluble $A \beta_{40}$

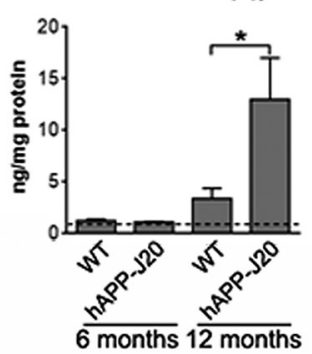

insoluble $\mathbf{A} \boldsymbol{\beta}_{42}$

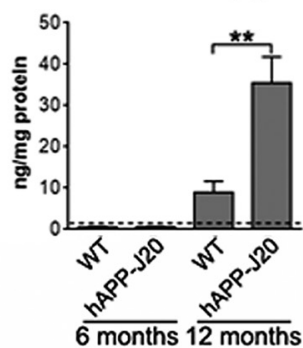

B

WT hAPP-J20
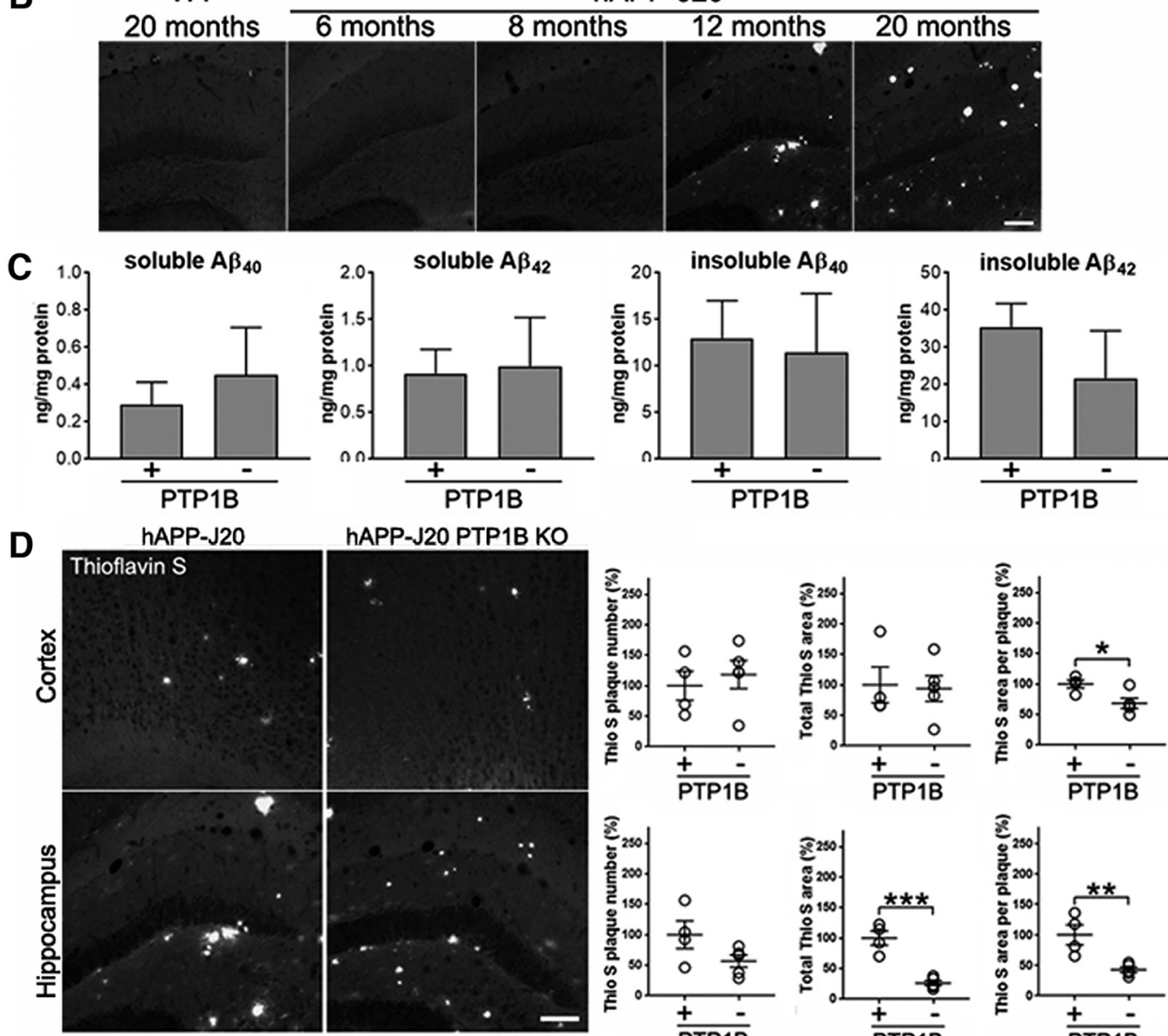
hAPP-J20 PTP1B KO
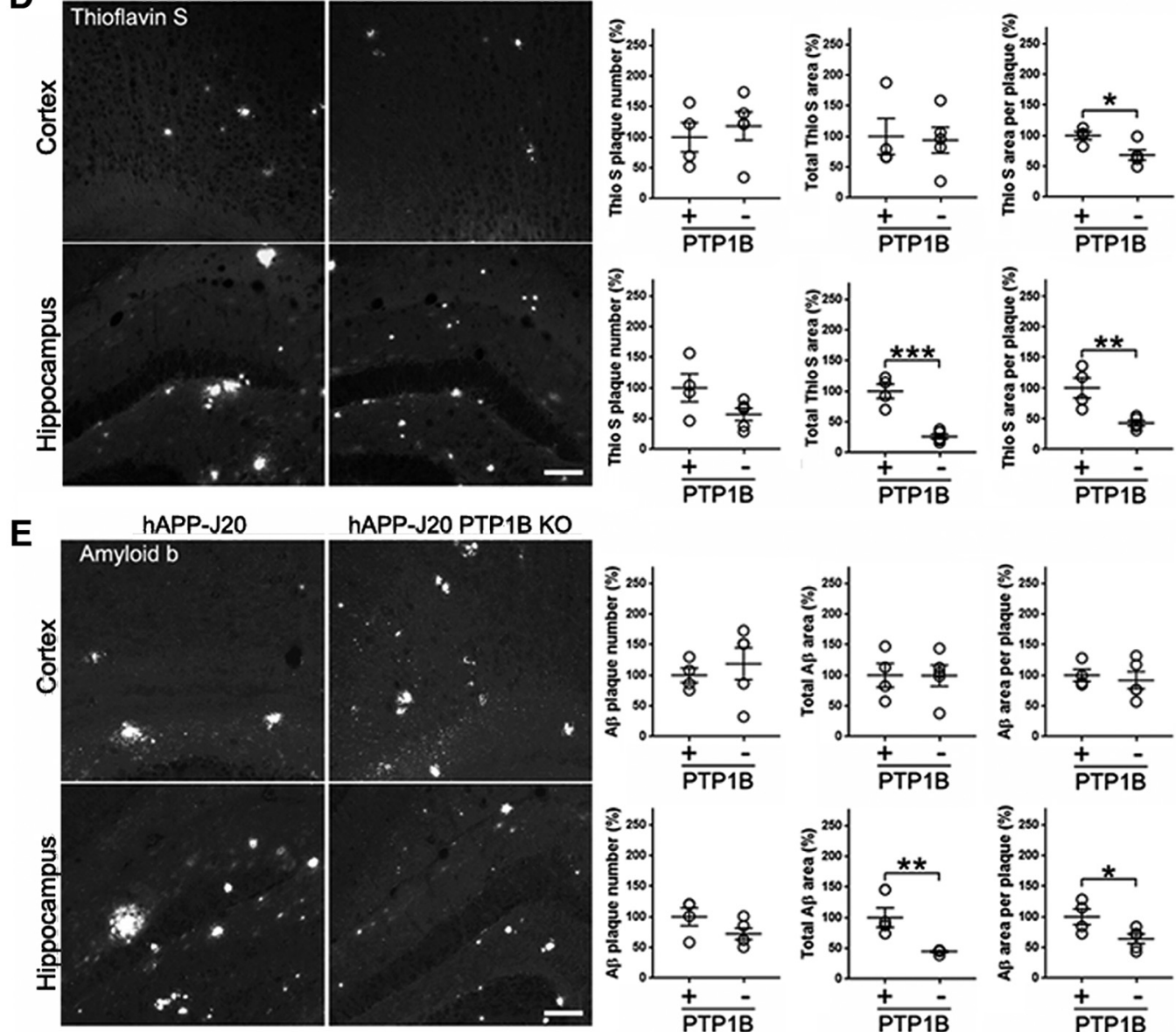

Figure 7. Neuronal PTP1B ablation reduces amyloid $\beta$ plaque burden in the hippocampus of hAPP-J20 mice. $A$, Soluble and insoluble A $\beta$ protein levels analyzed by ELISA with protein from hemispheres of hAPP-J20 and hAPP-J20 PTP1B KO mice at 6 and 12 months of age. $n=3-7$ mice/group. Only values above detection thresholds of the ELISAs (indicated by dashed lines) were considered for statistical analysis. Two-way ANOVA for soluble $A \beta_{42}$ : genotype, $F_{(1,19)}=6.422, p=0.202$; age, $F_{(1,19)}=5.526, p=0.0297$; interaction, (Figure legend continues.) 
J20 PTP1B KO mice compared with hAPP-J20 mice. The mean plaque areas were also significantly reduced in the hippocampus of hAPP-J20 PTP1B KO mice compared with hAPP-J20 mice.

Similarly, $A \beta$ plaque numbers were not different in hAPPJ20 and hAPP-J20 PTP1B KO mice (Fig. $7 E$ ), but each $A \beta$ plaque was smaller and the total $A \beta$ plaque area was reduced with neuronal PTP1B ablation. Together, these results suggest that PTP1B in neurons contributes to the accumulation of $A \beta$ plaques in hAPP-J20 mice, perhaps by interfering with plaque growth dynamics.

\section{Discussion}

The present study identifies neuronal PTP1B as a key component required for the manifestation of spatial memory deficits and neurodegeneration in a mouse model of familial AD. Systemic selective inhibition of PTP1B or PTP1B ablation in neurons was sufficient to ameliorate spatial learning and memory deficits of hAPP-J20 mice and prevent hippocampal neuron loss. These functional improvements were associated with restored phosphorylation and inhibition of cerebral GSK $3 \beta$. Inflammation in hAPP-J20 mice was suppressed by systemic inhibition of PTP1B, but not by neuronal PTP1B ablation. Finally, neuronal ablation of PTP1B decreased hippocampal $A \beta$ plaque size without altering cerebral $\mathrm{A} \beta$ protein levels. These findings imply that neuronal PTP1B drives the progression of AD in these mice.

PTP1B modulates multiple pathways and processes that are linked to neuropathological conditions, such as $\mathrm{AD}$ and dementia (Vieira et al., 2017). GSK3 $\beta$ is inactivated by phosphorylation mainly through the action of protein kinase $\mathrm{B}$ (PKB; Ueki et al., 1998). PTP1B indirectly suppresses PKB activity either by inactivating the insulin signaling pathway (Gum et al., 2003; Bence et al., 2006; Pandey et al., 2014) or by silencing the BDNF receptor trkB (Li et al., 2007; Ozek et al., 2014). Thus, in hAPP-J20 mice neuronal PTP1B may drive GSK3 $\beta$ activity by interfering with insulin signaling, as we observed here, and also by interfering with trkB signaling.

Suppressing GSK3 $\beta$ activity protects neurons from a variety of stressors and prevents cell death (D'Mello et al., 1994; Alvarez et al., 1999). In addition to its neurotoxic effects, GSK3 $\beta$ impairs memory performance: cerebral overexpression of GSK $3 \beta$ in mice disturbed spatial learning during Morris water maze experiments (Hernández et al., 2002), potentially due to interference with long-term potentiation (Hooper et al., 2007). Also, GSK3 $\beta$ alters synaptic remodeling by inhibiting cAMP responsive elementbinding protein (Hansen et al., 2004) and is involved in the regulation of cytoskeleton assembly (Koivisto et al., 2004), which is needed for synaptic reorganization during memory consolidation (Hooper et al., 2008). Thus, part of the beneficial effect of PTP1B inhibition or neuronal PTP1B ablation in neuronal loss

\footnotetext{
(Figure legend continued.) $\quad F_{(1,19)}=5.998, p=0.0242$. Post hoc pairwise comparison between WT and hAPP-J20 at 12 months, ${ }^{* *} p=0.0034$. Two-way ANOVA for insoluble $A \beta_{40}$ : genotype, $F_{(1,20)}=3.288, p=0.0848$; age, $F_{(1,20)}=7.173, p=0.0144$; interaction, $F_{(1,20)}=$ $3.456, p=0.0778$. Post hoc pairwise comparison between WT and hAPP-J20 at 12 months, ${ }^{*} p=0.0426$. Insoluble $A \beta_{42}$ : Student's $t$ test $(p=0.0022)$. $\boldsymbol{B}$, Hippocampal plaques were visualized by thioflavin $S$ staining at ages indicated. Scale bar, $100 \mu \mathrm{m}$. C, Soluble or insoluble $A \beta$ protein levels are compared by ELISA with protein from hemispheres of 12-month-old hAPP-J20 and hAPP-J20 PTP1B K0 mice ( $n=4-7$ mice/group). D, E, Thioflavin S-positive (D) and $A \beta$-positive $(\boldsymbol{E})$ plaques in the cortex and hippocampus were compared between hAPP-J20 and hAPP-J20 PTP1B KO mice at 12 months of age. Scale bar, $100 \mu \mathrm{m} . n=4-5$ mice/group. Student's $t$ test: $\boldsymbol{D},{ }^{* * *} p=0.0003,{ }^{* *} p=0.0067 ; \boldsymbol{E}_{1}{ }^{* *} p=0.0054,{ }^{*} p=0.0406$.
}

$\leftarrow$ and cognitive decline may result from restoring GSK3 $\beta$ phosphorylation/inhibition in this $\mathrm{AD}$ model.

Inflammation is a common phenomenon in $\mathrm{AD}$ (Heneka et al., 2015). However, it remains uncertain whether inflammatory processes in $\mathrm{AD}$ patients substantially contribute to tissue degradation or whether inflammation is rather a secondary effect in response to other pathological triggers (Akiyama et al., 2000). $\mathrm{APP}$ processing and $\mathrm{A} \beta$ accumulation result in the activation of microglia and astrocytes (Meraz-Ríos et al., 2013). We observed inflammation before the accumulation of $\mathrm{A} \beta$ protein and plaque deposition in hAPP-J20 mice, as reported by others (Wright et al., 2013), suggesting that inflammation is an early response in this $\mathrm{AD}$ model. Our data suggest that PTP1B contributes to inflammation in hAPP-J20 mice, since systemic inhibition of PTP1B resulted in reduced hippocampal microgliosis and astrogliosis. Consistent with our finding, intracerebral administration of a PTP1B inhibitor also reduces lipopolysaccharide-induced brain inflammation (Song et al., 2016). PTP1B could be activated as a result of endoplasmic reticulum stress from the toxicity of the mutant $\mathrm{A} \beta$ protein or as a consequence of inflammation.

Although inflammation coincides with cognitive impairment in hAPP-J20 mice, we were surprised to find that neuronal PTP1B ablation in these mice could rescue neurodegeneration and cognitive deficits without reducing inflammation. This finding is particularly interesting because it dissociates inflammation from learning and memory deficits in hAPP-J20 mice at 6 months of age. It remains to be determined whether this is also true in other mouse models of $\mathrm{AD}$ and even in humans afflicted with $\mathrm{AD}$. If so, this might explain why an anti-inflammatory strategy failed to show clinical therapeutic benefit (Meyer et al., 2019). Our previous work indicates that the small protein $\mathrm{LMO} 4$ is an endogenous inhibitor of PTP1B (Pandey et al., 2013; Qin et al., 2015b) and loss of LMO4 reported in the hippocampus of $\mathrm{AD}$ patients postmortem (Leuba et al., 2004) would be consistent with PTP1B activation.

Ablation of PTP1B in glutamatergic neurons did not alter $\mathrm{A} \beta_{40}$ or $\mathrm{A} \beta_{42}$ protein levels, but decreased $\mathrm{A} \beta$ plaque size. Interestingly, disease progression in patients does not correlate with plaque growth, probably due to the constant resolution of $\mathrm{A} \beta$ plaques (Hyman et al., 1993). The mechanism behind this dynamic equilibrium is largely unknown, and although plaque growth may be modulated by microgliosis and astrogliosis (Yan et al., 2009), our finding that inflammation is not altered by neuronal ablation of PTP1B yet plaque size was reduced argues against this mechanism. Our data imply that neuronal PTP1B contributes to plaque growth and/or impairs plaque resolution, but it remains uncertain how PTP1B affects plaque dynamics. PTP1B is activated by chronic sleep fragmentation (Hakim et al., 2015), a common condition of patients with AD (Brzecka et al., 2018). Hippocampal memory deficits in aging could be attributed to sleep disorders (Mander et al., 2013) that disrupt the normal oscillations in CSF flow from the brain coupled with the sleep cycle (Fultz et al., 2019). These oscillations may be important to clear toxic metabolites from the brain, including amyloid. Whether the beneficial effects of pharmacological and genetic targeting of PTP1B on learning and memory are also mediated by an improved sleep cycle is an intriguing possibility that merits further investigation.

A recent report showed that trodusquemine enhances $\mathrm{A} \beta_{42}$ aggregation but suppresses its toxicity by displacing oligomers from cell membranes in Caenorhabditis elegans (Limbocker et al., 2019). Whether these effects are mediated by the C. elegans PTP1B homolog MOA-1/R155.2 remains to be tested. Consistent 
with our findings, these authors saw no effect on $\mathrm{A} \beta_{42}$ protein levels with trodusquemine treatment. Trodusquemine (MSI1436), a natural compound, is a spermine metabolite of cholesterol that was isolated from dogfish shark liver (Rao et al., 2000; Zasloff et al., 2001). Trodusquemine is a reversible, noncompetitive inhibitor of PTP1B ( $K_{\mathrm{i}}, 600 \mathrm{~nm}$; Krishnan et al., 2014) with 200 -fold selectivity compared with the closest homolog TC-PTP (Lantz et al., 2010). Trodusquemine readily crosses the bloodbrain barrier, with a half-life of $>1$ week in vivo (Zasloff et al., 2001; Ahima et al., 2002; Lantz et al., 2010). By inhibiting PTP1B, trodusquemine promotes insulin and leptin signaling (Ahima et al., 2002; Lantz et al., 2010; Roitman et al., 2010), and, since trodusquemine has undergone clinical trials for safety and for the treatment of obesity (Nguyen et al., 2013), it could be readily repurposed to treat $\mathrm{AD}$.

Our study showed that trodusquemine robustly ameliorated AD symptoms in the hAPP-J20 mouse model, but also induced weight loss. Before transition to clinical studies, the lowest optimal effective dose of trodusquemine should be determined, with minimal weight loss and maximal effect on the $\mathrm{AD}$ phenotype. Furthermore, it will be important to test this therapeutic approach in other models of $\mathrm{AD}$, particularly in models with tau pathologies. It is worth noting that GSK3 $\beta$ drives the production of tau protein and its aggregation to neurofibrillary tangles (Hooper et al., 2008). GSK3 $\beta$ inhibitors were shown to be beneficial in AD rodent models, but have side effects that induce apoptosis and memory impairment in healthy controls ( $\mathrm{Hu}$ et al., 2009). However, a phase 2 clinical trial of GSK3 $\beta$ inhibitor found no clinical benefit (Lovestone et al., 2015). Since our data show that PTP1B is upstream of GSK3 $\beta$ activation, targeting GSK3 $\beta$ alone may be insufficient to improve AD. Trodusquemine does not harm cerebral integrity or cognitive performance of WT mice, as we reported previously (Qin et al., 2015b). Thus, the inhibition of PTP1B by trodusquemine or related compounds (Qin et al., 2015a) would be a preferable target to attenuate GSK3 $\beta$ hyperactivity in AD.

In summary, we show that neuronal PTP1B is required for neuron loss and memory impairment in this mouse model of familial AD. In addition, we demonstrate a novel pharmacological approach to ameliorate the progression of this devastating neurological disorder.

\section{References}

Ahima RS, Patel HR, Takahashi N, Qi Y, Hileman SM, Zasloff MA (2002) Appetite suppression and weight reduction by a centrally active aminosterol. Diabetes 51:2099-2104.

Akiyama H, Barger S, Barnum S, Bradt B, Bauer J, Cole GM, Cooper NR, Eikelenboom P, Emmerling M, Fiebich BL, Finch CE, Frautschy S, Griffin WS, Hampel H, Hull M, Landreth G, Lue L, Mrak R, Mackenzie IR, McGeer PL, et al. (2000) Inflammation and Alzheimer's disease. Neurobiol Aging 21:383-421.

Alvarez G, Muñoz-Montaño JR, Satrústegui J, Avila J, Bogónez E, Díaz-Nido J (1999) Lithium protects cultured neurons against $\beta$-amyloid-induced neurodegeneration. FEBS Lett 453:260-264.

Ballard C, Gauthier S, Corbett A, Brayne C, Aarsland D, Jones E (2011) Alzheimer's disease. Lancet 377:1019-1031.

Banh RS, Iorio C, Marcotte R, Xu Y, Cojocari D, Rahman AA, Pawling J, Zhang W, Sinha A, Rose CM, Isasa M, Zhang S, Wu R, Virtanen C, Hitomi T, Habu T, Sidhu SS, Koizumi A, Wilkins SE, Kislinger T, et al. (2016) PTP1B controls non-mitochondrial oxygen consumption by regulating RNF213 to promote tumour survival during hypoxia. Nat Cell Biol 18: 803-813.

Bence KK, Delibegovic M, Xue B, Gorgun CZ, Hotamisligil GS, Neel BG, Kahn BB (2006) Neuronal PTP1B regulates body weight, adiposity and leptin action. Nat Med 12:917-924.
Bloom GS (2014) Amyloid- $\beta$ and tau: the trigger and bullet in Alzheimer disease pathogenesis. JAMA Neurol 71:505-508.

Bonda DJ, Stone JG, Torres SL, Siedlak SL, Perry G, Kryscio R, Jicha G, Casadesus G, Smith MA, Zhu X, Lee HG (2014) Dysregulation of leptin signaling in Alzheimer disease: evidence for neuronal leptin resistance. J Neurochem 128:162-172.

Brzecka A, Leszek J, Ashraf GM, Ejma M, Ávila-Rodriguez MF, Yarla NS, Tarasov VV, Chubarev VN, Samsonova AN, Barreto GE, Aliev G (2018) Sleep disorders associated with Alzheimer's disease: a perspective. Front Neurosci 12:330.

Burns A, Iliffe S (2009) Alzheimer's disease. BMJ 338:b158.

Cai H, Cong WN, Ji S, Rothman S, Maudsley S, Martin B (2012) Metabolic dysfunction in Alzheimer's disease and related neurodegenerative disorders. Curr Alzheimer Res 9:5-17.

Casali BT, Landreth GE (2016) A $\beta$ extraction from murine brain homogenates. Bio Protoc 6:e1787.

Casanova E, Fehsenfeld S, Mantamadiotis T, Lemberger T, Greiner E, Stewart AF, Schütz G (2001) A CamKII $\alpha$ iCre BAC allows brain-specific gene inactivation. Genesis 31:37-42.

D’Mello SR, Anelli R, Calissano P (1994) Lithium induces apoptosis in immature cerebellar granule cells but promotes survival of mature neurons. Exp Cell Res 211:332-338.

Ferri CP, Prince M, Brayne C, Brodaty H, Fratiglioni L, Ganguli M, Hall K, Hasegawa K, Hendrie H, Huang Y, Jorm A, Mathers C, Menezes PR, Rimmer E, Scazufca M (2005) Global prevalence of dementia: a Delphi consensus study. Lancet 366:2112-2117.

Fultz NE, Bonmassar G, Setsompop K, Stickgold RA, Rosen BR, Polimeni JR, Lewis LD (2019) Coupled electrophysiological, hemodynamic, and cerebrospinal fluid oscillations in human sleep. Science 366:628-631.

Gandy S (2005) The role of cerebral amyloid $\beta$ accumulation in common forms of Alzheimer disease. J Clin Invest 115:1121-1129.

Gerakis Y, Hetz C (2018) Emerging roles of ER stress in the etiology and pathogenesis of Alzheimer's disease. FEBS J 285:995-1011.

Goldstein BJ, Bittner-Kowalczyk A, White MF, Harbeck M (2000) Tyrosine dephosphorylation and deactivation of insulin receptor substrate-1 by protein-tyrosine phosphatase 1B. possible facilitation by the formation of a ternary complex with the Grb2 adaptor protein. J Biol Chem 275:42834289.

Gum RJ, Gaede LL, Koterski SL, Heindel M, Clampit JE, Zinker BA, Trevillyan JM, Ulrich RG, Jirousek MR, Rondinone CM (2003) Reduction of protein tyrosine phosphatase $1 \mathrm{~B}$ increases insulin-dependent signaling in ob/ob mice. Diabetes 52:21-28.

Hakim F, Wang Y, Carreras A, Hirotsu C, Zhang J, Peris E, Gozal D (2015) Chronic sleep fragmentation during the sleep period induces hypothalamic endoplasmic reticulum stress and PTP1b-mediated leptin resistance in male mice. Sleep 38:31-40.

Hansen Tv, Rehfeld JF, Nielsen FC (2004) GSK-3 $\beta$ reduces cAMP-induced cholecystokinin gene expression by inhibiting CREB binding. Neuroreport 15:841-845.

Heneka MT, Carson MJ, El Khoury J, Landreth GE, Brosseron F, Feinstein DL, Jacobs AH, Wyss-Coray T, Vitorica J, Ransohoff RM, Herrup K, Frautschy SA, Finsen B, Brown GC, Verkhratsky A, Yamanaka K, Koistinaho J, Latz E, Halle A, Petzold GC, et al. (2015) Neuroinflammation in Alzheimer's disease. Lancet Neurol 14:388-405.

Hernández F, Borrell J, Guaza C, Avila J, Lucas JJ (2002) Spatial learning deficit in transgenic mice that conditionally over-express GSK- $3 \beta$ in the brain but do not form tau filaments. J Neurochem 83:1529-1533.

Hooper C, Markevich V, Plattner F, Killick R, Schofield E, Engel T, Hernandez F, Anderton B, Rosenblum K, Bliss T, Cooke SF, Avila J, Lucas JJ, Giese KP, Stephenson J, Lovestone S (2007) Glycogen synthase kinase-3 inhibition is integral to long-term potentiation. Eur J Neurosci 25:81-86

Hooper C, Killick R, Lovestone S (2008) The GSK3 hypothesis of Alzheimer's disease. J Neurochem 104:1433-1439.

Hu S, Begum AN, Jones MR, Oh MS, Beech WK, Beech BH, Yang F, Chen P, Ubeda OJ, Kim PC, Davies P, Ma Q, Cole GM, Frautschy SA (2009) GSK3 inhibitors show benefits in an Alzheimer's disease (AD) model of neurodegeneration but adverse effects in control animals. Neurobiol Dis 33:193-206.

Hyman BT, Marzloff K, Arriagada PV (1993) The lack of accumulation of 
senile plaques or amyloid burden in Alzheimer's disease suggests a dynamic balance between amyloid deposition and resolution. J Neuropathol Exp Neurol 52:594-600.

Jährling N, Becker K, Wegenast-Braun BM, Grathwohl SA, Jucker M, Dodt HU (2015) Cerebral $\beta$-amyloidosis in mice investigated by ultramicroscopy. PLoS One 10:e0125418.

Kayed R, Head E, Thompson JL, McIntire TM, Milton SC, Cotman CW, Glabe CG (2003) Common structure of soluble amyloid oligomers implies common mechanism of pathogenesis. Science 300:486-489.

Koivisto L, Häkkinen L, Matsumoto K, McCulloch CA, Yamada KM, Larjava H (2004) Glycogen synthase kinase-3 regulates cytoskeleton and translocation of Racl in long cellular extensions of human keratinocytes. Exp Cell Res 293:68-80.

Krishnan N, Koveal D, Miller DH, Xue B, Akshinthala SD, Kragelj J, Jensen MR, Gauss CM, Page R, Blackledge M, Muthuswamy SK, Peti W, Tonks NK (2014) Targeting the disordered C terminus of PTP1B with an allosteric inhibitor. Nat Chem Biol 10:558-566.

Lantz KA, Hart SG, Planey SL, Roitman MF, Ruiz-White IA, Wolfe HR, McLane MP (2010) Inhibition of PTP1B by trodusquemine (MSI-1436) causes fat-specific weight loss in diet-induced obese mice. Obesity 18 : $1516-1523$.

Leibson CL, Rocca WA, Hanson VA, Cha R, Kokmen E, O’Brien PC, Palumbo PJ (1997) Risk of dementia among persons with diabetes mellitus: a population-based cohort study. Am J Epidemiol 145:301-308.

Leuba G, Vernay A, Vu D, Walzer C, Belloir B, Kraftsik R, Bouras C, Savioz A (2004) Differential expression of LMO4 protein in Alzheimer's disease. Neuropathol Appl Neurobiol 30:57-69.

Li Z, Tan F, Thiele CJ (2007) Inactivation of glycogen synthase kinase- $3 \beta$ contributes to brain-derived neutrophic factor/TrkB-induced resistance to chemotherapy in neuroblastoma cells. Mol Cancer Ther 6:3113-3121.

Limbocker R, Chia S, Ruggeri FS, Perni M, Cascella R, Heller GT, Meisl G, Mannini B, Habchi J, Michaels TCT, Challa PK, Ahn M, Casford ST, Fernando N, Xu CK, Kloss ND, Cohen SIA, Kumita JR, Cecchi C, Zasloff $\mathrm{M}$, et al. (2019) Trodusquemine enhances Abeta42 aggregation but suppresses its toxicity by displacing oligomers from cell membranes. Nat Commun 10:225.

Llorens-Martín M, Jurado J, Hernández F, Avila J (2014) GSK-3 $\beta$, a pivotal kinase in Alzheimer disease. Front Mol Neurosci 7:46.

Lovestone S, Boada M, Dubois B, Hüll M, Rinne JO, Huppertz HJ, Calero M, Andrés MV, Gómez-Carrillo B, León T, del Ser T (2015) A phase II trial of tideglusib in Alzheimer's disease. J Alzheimers Dis 45:75-88.

Luchsinger JA, Tang MX, Stern Y, Shea S, Mayeux R (2001) Diabetes mellitus and risk of Alzheimer's disease and dementia with stroke in a multiethnic cohort. Am J Epidemiol 154:635-641.

Mander BA, Rao V, Lu B, Saletin JM, Lindquist JR, Ancoli-Israel S, Jagust W, Walker MP (2013) Prefrontal atrophy, disrupted NREM slow waves and impaired hippocampal-dependent memory in aging. Nat Neurosci 16: 357-364.

Meraz-Ríos MA, Toral-Rios D, Franco-Bocanegra D, Villeda-Hernández J, Campos-Peña V (2013) Inflammatory process in Alzheimer's disease. Front Integr Neurosci 7:59.

Meyer PF, Tremblay-Mercier J, Leoutsakos J, Madjar C, Lafaille-Maignan ME, Savard M, Rosa-Neto P, Poirier J, Etienne P, Breitner J, Group P-AR (2019) INTREPAD: a randomized trial of naproxen to slow progress of presymptomatic Alzheimer disease. Neurology 92:e2070e2080.

Mucke L, Masliah E, Yu GQ, Mallory M, Rockenstein EM, Tatsuno G, Hu K, Kholodenko D, Johnson-Wood K, McConlogue L (2000) High-level neuronal expression of $\mathrm{A} \beta 1-42$ in wild-type human amyloid protein precursor transgenic mice: synaptotoxicity without plaque formation. J Neurosci 20:4050-4058.

Mullan M, Crawford F, Axelman K, Houlden H, Lilius L, Winblad B, Lannfelt L (1992) A pathogenic mutation for probable Alzheimer's disease in the APP gene at the N-terminus of beta-amyloid. Nat Genet 1:345-347.

Murrell JR, Hake AM, Quaid KA, Farlow MR, Ghetti B (2000) Early-onset Alzheimer disease caused by a new mutation (V717L) in the amyloid precursor protein gene. Arch Neurol 57:885-887.

Nguyen LK, Matallanas D, Croucher DR, von Kriegsheim A, Kholodenko BN (2013) Signalling by protein phosphatases and drug development: a systems-centred view. FEBS J 280:751-765.
Nordberg A, Rinne JO, Kadir A, Långström B (2010) The use of PET in Alzheimer disease. Nat Rev Neurol 6:78-87.

Ozek C, Kanoski SE, Zhang ZY, Grill HJ, Bence KK (2014) Protein-tyrosine phosphatase 1B (PTP1B) is a novel regulator of central brain-derived neurotrophic factor and tropomyosin receptor kinase B (TrkB) signaling. J Biol Chem 289:31682-31692.

Palop JJ, Jones B, Kekonius L, Chin J, Yu GQ, Raber J, Masliah E, Mucke L (2003) Neuronal depletion of calcium-dependent proteins in the dentate gyrus is tightly linked to Alzheimer's disease-related cognitive deficits. Proc Natl Acad Sci U S A 100:9572-9577.

Pandey NR, Zhou X, Qin Z, Zaman T, Gomez-Smith M, Keyhanian K, Anisman H, Brunel JM, Stewart AF, Chen HH (2013) The LIM domain only 4 protein is a metabolic responsive inhibitor of protein tyrosine phosphatase $1 \mathrm{~B}$ that controls hypothalamic leptin signaling. J Neurosci 33:12647-12655.

Pandey NR, Zhou X, Zaman T, Cruz SA, Qin Z, Lu M, Keyhanian K, Brunel JM, Stewart AF, Chen HH (2014) LMO4 is required to maintain hypothalamic insulin signaling. Biochem Biophys Res Commun 450:666-672.

Profenno LA, Porsteinsson AP, Faraone SV (2010) Meta-analysis of Alzheimer's disease risk with obesity, diabetes, and related disorders. Biol Psychiatry 67:505-512.

Qin Z, Pandey NR, Zhou X, Stewart CA, Hari A, Huang H, Stewart AF, Brunel JM, Chen HH (2015a) Functional properties of claramine: a novel PTP1B inhibitor and insulin-mimetic compound. Biochem Biophys Res Commun 458:21-27.

Qin Z, Zhou X, Pandey NR, Vecchiarelli HA, Stewart CA, Zhang X, Lagace DC, Brunel JM, Béique JC, Stewart AF, Hill MN, Chen HH (2015b) Chronic stress induces anxiety via an amygdalar intracellular cascade that impairs endocannabinoid signaling. Neuron 85:1319-1331.

Rao MN, Shinnar AE, Noecker LA, Chao TL, Feibush B, Snyder B, Sharkansky I, Sarkahian A, Zhang X, Jones SR, Kinney WA, Zasloff M (2000) Aminosterols from the dogfish shark squalus acanthias. J Nat Prod 63:631-635.

Roitman MF, Wescott S, Cone JJ, McLane MP, Wolfe HR (2010) MSI-1436 reduces acute food intake without affecting dopamine transporter activity. Pharmacol Biochem Behav 97:138-143.

Royea J, Zhang L, Tong XK, Hamel E (2017) Angiotensin IV receptors mediate the cognitive and cerebrovascular benefits of losartan in a mouse model of Alzheimer's disease. J Neurosci 37:5562-5573.

Schock SC, Xu J, Duquette PM, Qin Z, Lewandowski AJ, Rai PS, Thompson CS, Seifert EL, Harper ME, Chen HH (2008) Rescue of neurons from ischemic injury by peroxisome proliferator-activated receptorgamma requires a novel essential cofactor LMO4. J Neurosci 28: 12433-12444.

Selkoe DJ (1991) The molecular pathology of Alzheimer's disease. Neuron 6:487-498.

Song GJ, Jung M, Kim JH, Park H, Rahman MH, Zhang S, Zhang ZY, Park DH, Kook H, Lee IK, Suk K (2016) A novel role for protein tyrosine phosphatase $1 \mathrm{~B}$ as a positive regulator of neuroinflammation. J Neuroinflammation 13:86.

Spires-Jones TL, Hyman BT (2014) The intersection of amyloid beta and tau at synapses in Alzheimer's disease. Neuron 82:756-771.

Steculorum SM, Solas M, Brüning JC (2014) The paradox of neuronal insulin action and resistance in the development of aging-associated diseases. Alzheimers Dement 10:S3-S11.

Takashima A (2006) GSK-3 is essential in the pathogenesis of Alzheimer's disease. J Alzheimers Dis 9:309-317.

Tsunekawa T, Banno R, Mizoguchi A, Sugiyama M, Tominaga T, Onoue T, Hagiwara D, Ito Y, Iwama S, Goto M, Suga H, Sugimura Y, Arima H (2017) Deficiency of PTP1B attenuates hypothalamic inflammation via activation of the JAK2-STAT3 pathway in microglia. EBioMedicine 16: 172-183.

Ueki K, Yamamoto-Honda R, Kaburagi Y, Yamauchi T, Tobe K, Burgering BM, Coffer PJ, Komuro I, Akanuma Y, Yazaki Y, Kadowaki T (1998) Potential role of protein kinase B in insulin-induced glucose transport, glycogen synthesis, and protein synthesis. J Biol Chem 273: 5315-5322.

van der Flier WM, Scheltens P (2005) Epidemiology and risk factors of dementia. J Neurol Neurosurg Psychiatry 76:v2-v7.

Vieira MNN, Lyra E Silva NM, Ferreira ST, De Felice FG (2017) Protein tyrosine phosphatase 1B (PTP1B): a potential target for Alzheimer's therapy? Front Aging Neurosci 9:7. 
Wright AL, Zinn R, Hohensinn B, Konen LM, Beynon SB, Tan RP, Clark IA, Abdipranoto A, Vissel B (2013) Neuroinflammation and neuronal loss precede $\mathrm{A} \beta$ plaque deposition in the hAPP-J20 mouse model of Alzheimer's disease. PLoS One 8:e59586.

Yan P, Bero AW, Cirrito JR, Xiao Q, Hu X, Wang Y, Gonzales E, Holtzman DM, Lee JM (2009) Characterizing the appearance and growth of amyloid plaques in APP/PS1 mice. J Neurosci 29:10706-10714.

Zabolotny JM, Kim YB, Welsh LA, Kershaw EE, Neel BG, Kahn BB (2008) Protein-tyrosine phosphatase $1 \mathrm{~B}$ expression is induced by inflammation in vivo. J Biol Chem 283:14230-14241.

Zaman T, Zhou X, Pandey NR, Qin Z, Keyhanian K, Wen K, Courtney RD, Stewart AF, Chen HH (2014) LMO4 is essential for paraventricular hy- pothalamic neuronal activity and calcium channel expression to prevent hyperphagia. J Neurosci 34:140-148.

Zasloff M, Williams JI, Chen Q, Anderson M, Maeder T, Holroyd K, Jones S, Kinney W, Cheshire K, McLane M (2001) A spermine-coupled cholesterol metabolite from the shark with potent appetite suppressant and antidiabetic properties. Int J Obes Relat Metab Disord 25:689-697.

Zhang F, Kang Z, Li W, Xiao Z, Zhou X (2012) Roles of brain-derived neurotrophic factor/tropomyosin-related kinase $\mathrm{B}$ (BDNF/TrkB) signalling in Alzheimer's disease. Journal of Clinical Neuroscience 19:946-949.

Zhu X, Zhou Y, Tao R, Zhao J, Chen J, Liu C, Xu Z, Bao G, Zhang J, Chen M, Shen J, Cheng C, Zhang D (2015) Upregulation of PTP1B after rat spinal cord injury. Inflammation 38:1891-1902. 